Article

\title{
Final-Stage Magmatic Record of Paleo-Asian Oceanic Subduction? Insights from Late Permian to Early Triassic Intrusive Rocks in the Yanbian Area, Easternmost Central Asian Orogenic Belt
}

\author{
Chao Zhang ${ }^{1,2,3}$, Franz Neubauer ${ }^{2}$, Zheng-Hong Liu ${ }^{3,4, *}$, Fang-Hua Cui ${ }^{1,3}$ \\ and Qing-Bin Guan 5,6 \\ 1 The School of Resources and Environmental Engineering, Shandong University of Technology, \\ Zibo 255049, China; czhang@sdut.edu.cn (C.Z.); cuifanghua@sdut.edu.cn (F.-H.C.) \\ 2 Department of Geography and Geology, University of Salzburg, 5200 Salzburg, Austria; \\ Franz.Neubauer@sbg.ac.at \\ 3 Key Laboratory of Mineral Resources Evaluation in Northeast Asia, Ministry of Land and Resources, \\ Changchun 130061, China \\ 4 College of Earth Science, Jilin University, Changchun 130061, China \\ 5 Key Lab of Submarine Geoscience and Prospecting Techniques, MOE, Institute for Advanced Ocean Study, \\ College of Marine Geosciences, Ocean University of China, Qingdao 266100, China; \\ guanqingbin@ouc.edu.cn \\ 6 Laboratory for Marine Mineral Resources, Qingdao National Laboratory for Marine Science and Technology, \\ Qingdao 266237, China \\ * Correspondence: zhliu@jlu.edu.cn
}

Received: 8 July 2020; Accepted: 7 September 2020; Published: 10 September 2020

\begin{abstract}
This paper reports new zircon LA-ICP-MS U-Pb and Hf isotope data, and whole-rock major and trace element data for Late Permian to Early Triassic intrusive rocks in the Yanbian area, NE China. These data provide new insights into the timing of the final subduction of the Paleo-Asian Ocean beneath the North China Craton. The zircon $\mathrm{U}-\mathrm{Pb}$ age data indicate that a suite of Late Permian to Early Triassic intrusive rocks related to subduction is present within the Yanbian area. The Late Permian intrusive rocks consist of diorites while the Early Triassic granites and hornblende gabbros constitute a geochemically bimodal igneous rock association. Furthermore, the Early Triassic granites show the geochemical characteristics of shoshonitic rocks. All the rocks are characterized by enrichment in LILEs and LREEs, and depletion in HREEs and HFSEs, suggesting they formed in a subduction setting. Zircons from the Early Triassic gabbros have $\varepsilon_{\mathrm{Hf}}(\mathrm{t})$ values and $\mathrm{T}_{\mathrm{DM} 2}$ ages of +7.6 to +10.7 and 735-1022 Ma, respectively, suggesting that they formed from a primary magma generated by the partial melting of lithospheric mantle material that had been previously modified by subduction-related fluids. The Late Permian diorites have $\varepsilon_{\mathrm{Hf}}(\mathrm{t})$ values and $\mathrm{T}_{\mathrm{DM} 2}$ ages of +0.5 to +9.5 and 853 to $1669 \mathrm{Ma}$, respectively, while they have high contents of $\mathrm{Al}_{2} \mathrm{O}_{3}, \mathrm{Fe}_{2} \mathrm{O}_{3}$, and low contents of $\mathrm{SiO}_{2}, \mathrm{Cr}$, and $\mathrm{Ni}$, indicating Late Permian diorites should derive from the mantle and are influenced by some crustal material. Early Triassic granitic rocks have a wide range of $\varepsilon_{\mathrm{Hf}}(\mathrm{t})$ values and $\mathrm{T}_{\mathrm{DM} 2}$ ages of -4.8 to +9.4 and 852 to $2136 \mathrm{Ma}$, respectively. Their zircons imply that the Early Triassic granites could be mainly derived from partial melting of the crust, with minor contribution of the crustal material of an ancient crust. The Early Triassic bimodal intrusive rocks in Yanbian area, combined with the regional geologic information; therefore, record a final post-subduction extensional environment due to the break-off of the previously subducted slab.
\end{abstract}

Keywords: Central Asian Orogenic Belt; Paleo-Asian Ocean; NE China; Yanbian area; bimodal igneous rocks 


\section{Introduction}

The Central Asian Orogenic Belt (CAOB) underwent a long history from the breakup of Rodinia to the convergence of Pangea and its evolution is related to the opening, subduction, and closure of the Paleo-Asian Ocean between Neoproterozoic and Late Paleozoic times [1-4]. Northeast (NE) China is located at the eastern segment of the CAOB between the Siberian Craton and the North China Craton (Figure 1) [4-7]. It was formed by long-lived subduction, continental margin accretion, and continent-arc-continent collision due to the closure of the Paleo-Asian Ocean and is a key element for understanding the evolution of the eastern CAOB [4,8-13]. Previous studies have suggested that the closure of the Paleo-Asian Ocean is a scissor-like closure process [4,11]; however, the precise timing of the final closure of the Paleo-Asian Ocean is controversial, and includes proposals for Middle to Late Devonian, Late Devonian to Early Carboniferous, Late Permian, Late Permian to Early Triassic, or even Middle to Late Triassic timing [4,5,10,11,14-17]. Moreover, the location of final closure of the Paleo-Asian Ocean in NE China is still remaining controversial $[4,15,17,18]$. Previous studies have focused on the evolution of the Paleo-Asian Ocean in the eastern CAOB along the Solonker-Xar Moron-Changchun suture zone [4,8,10,14,19-21], whereas few studies of the tectonic evolution have been studied the easternmost part of the CAOB. Thus, it remains debated on whether the final suture location of Paleo-Asian Ocean extends to Yanbian area at the eastern termination of CAOB. In summary, research on the Paleozoic tectonic evolution in the Yanbian area, the easternmost CAOB, is meaningful for understanding the final timing and mode of Paleo-Asian Ocean closure. In this paper, we present new petrological, geochronological and geochemical data of Late Permian-Early Triassic intrusive rocks in the Helong area, the Yanbian area, to constrain the final tectonic evolution stage of the easternmost $\mathrm{CAOB}$ and shed new light on the timing of the final closure of the Paleo-Asian Ocean.

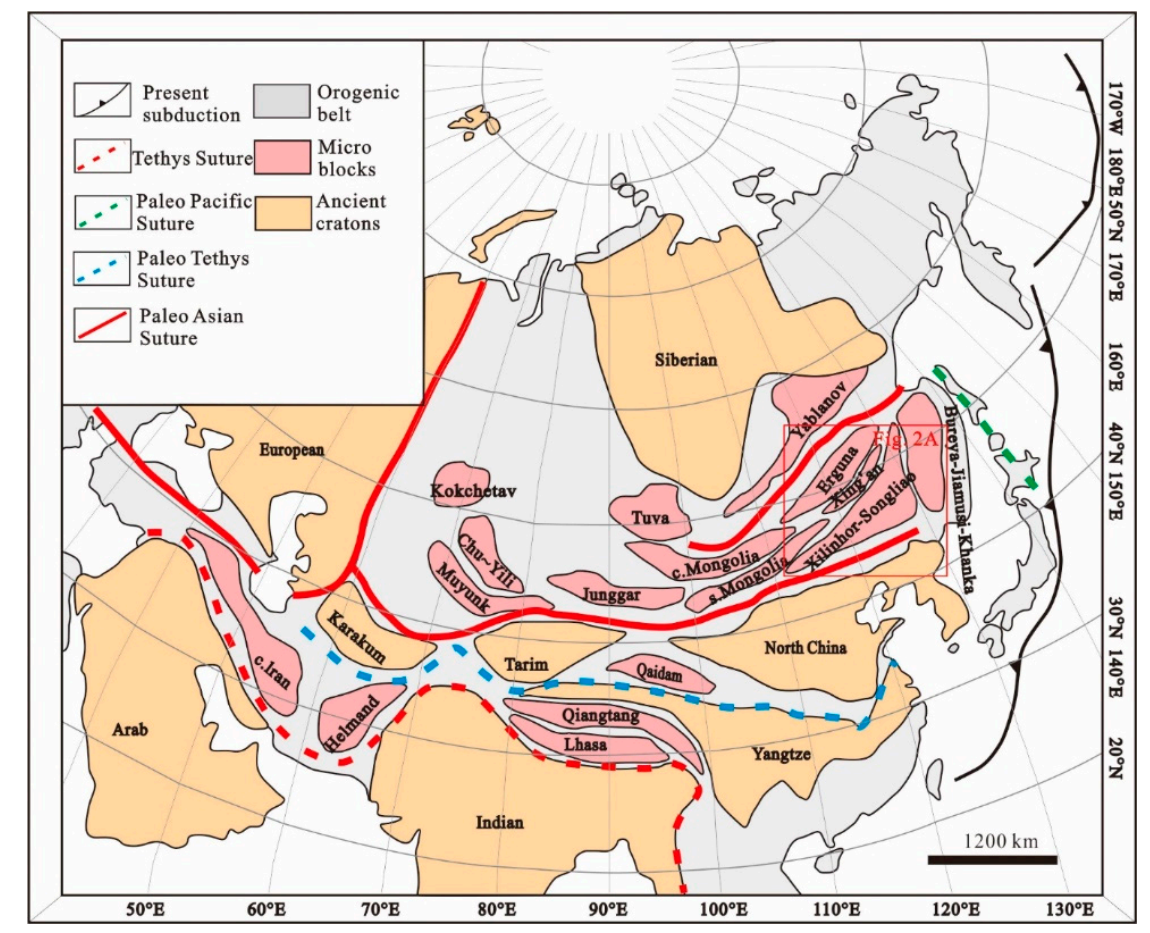

Figure 1. Tectonic sketch map of Central Asian Orogenic Belt and the location of Northeast China (modified after Liu et al. [4]). 


\section{Geological Background and Sample Descriptions}

The Yanbian area in NE China, belonging to the easternmost part of the CAOB, is located at the junction of the Jiamusi Block, the Khanka block, and the North China Craton (NCC) (Figure 2A) [4,5,21-25]. This area is bounded by the Dunhua-Mishan fault to the northwest and by the Gudonghe-Fuerhe fault to the south (Figure 2). Due to being the part of the Paleo-Asian Ocean and Paleo-Pacific tectonic domains, the Yanbian area contains numerous Phanerozoic igneous rocks, which are associated with significant deposits such as gold, copper, molybdenum, and iron $[5,23,26,27]$. Additionally, the sedimentary rocks, metamorphic events and tectonic deformation in Yanbian area are also related to the tectonic evolution of Paleo-Asian and Paleo-Pacific Oceans $[5-7,15,25,28,29]$. Despite considerable research carried out over a long time, confusion remains regarding the Permo-Triassic igneous rocks in the Yanbian area [5,12,22,24,30-35]. Many studies imply that the Permo-Triassic igneous rocks are associated with the tectonic evolution Paleo-Asian Ocean $[5,15,17,28,29]$. Whereas a few studies have proposed that they are related to the subduction of the Paleo-Pacific Ocean [35].

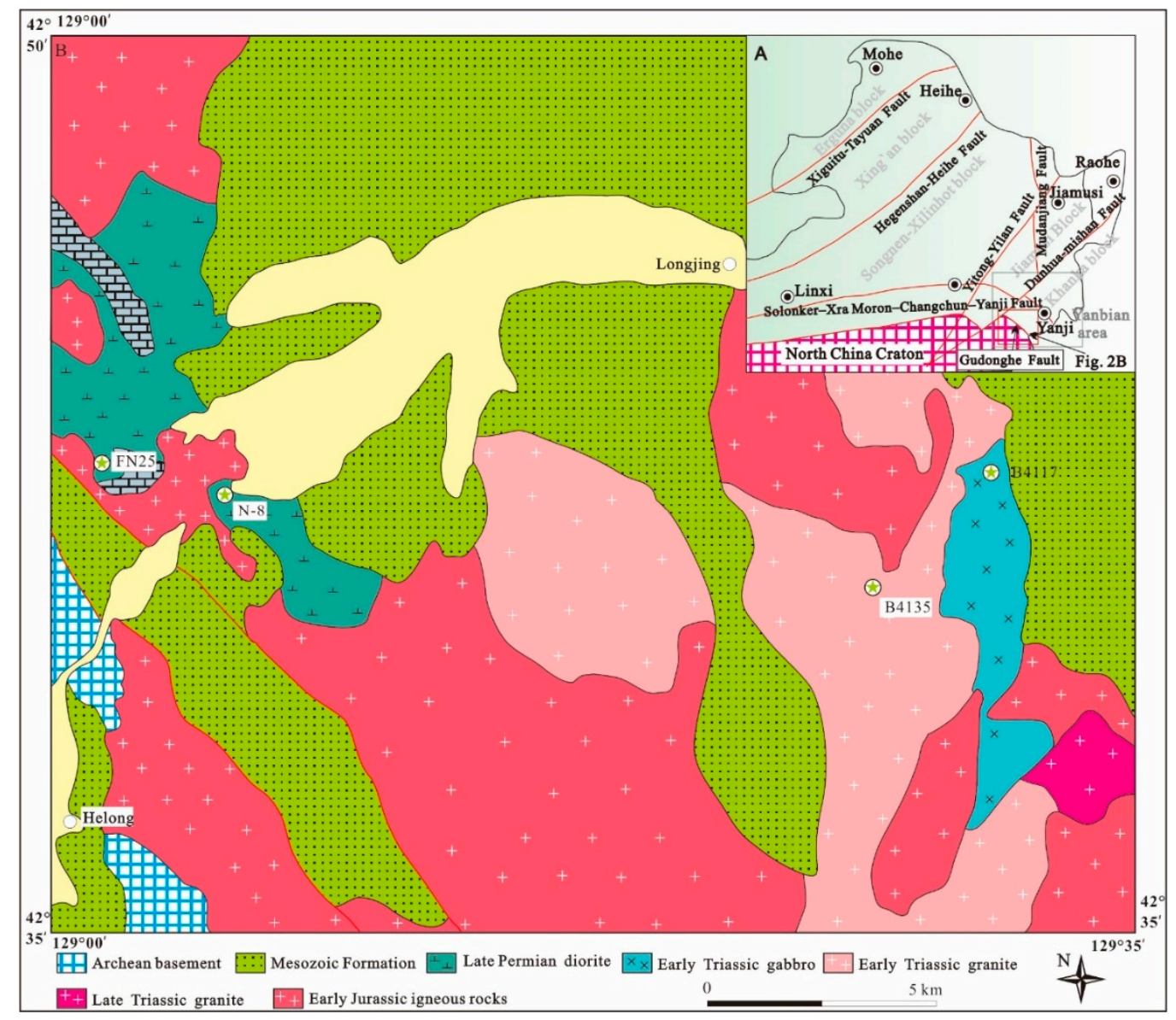

Figure 2. (A) Tectonic sketch map of Northeast China. (B) Geological map of the Yanbian area.

The study area is to the east of Helong City, in the southern Yanbian area (Figure 2B) and is located at the eastern segment of the CAOB. The basement of the study area is the Neo-Archean Guandi Formation and the outcropping strata mainly include Mesozoic sedimentary and volcanic rocks [34,36-38]. The Mesozoic sedimentary and volcanic rocks are mainly composed of Cretaceous continental volcanic clastic rocks and sandstones, and these Cretaceous rocks are deposited in the Cretaceous basins which are controlled by the faults and have no deformations. However, the Paleozoic strata are rare and difficult to analyze. In the study area, the Fuerhe-Gudonghe fault extends in the NNW-direction. Voluminous igneous rocks distribute along the fault. However, these igneous 
rocks are classified as late Paleozoic based on K-Ar ages and lithostratigraphic relationships [36]. Thus, previous studies have shown that the voluminous igneous rocks include Late Permian-Cretaceous rocks [5,16,34,37,38]. Furthermore, according to their emplacement ages, the Late Permian-Triassic igneous rocks in study area could be divided into the three groups: (1) Late Permian, (2) Early Triassic, and (3) Middle Triassic [5,16,30,34,37]. However, the poor exposure of Paleozoic strata made it too difficult to analyze the tectonic evolution. Therefore, a workable way is to analyze the change in tectonic settings based on the composition and ages of igneous rocks. Then the pure geological characteristic of studied area becomes clear. In this study, we analyzed three Late Permian to Early Triassic plutons in the Helong area, with the aim to reveal their petrogenesis and tectonic setting combined with the coeval, associated rock association. The Late Permian to Early Triassic plutons have a limited distributed in the study area and are named as metamorphic Xindongcun Group in earlier studies [36]. These geological bodies are covered by Mesozoic strata and are intruded by Jurassic plutons. Unfortunately, the geological relationships of these geological bodies are unclear due to the effect of extensive vegetation cover. The representative photographs of studied plutonic rocks are shown in Figure 3. The Late Permian intrusive rocks are exposed in limited areas and are mainly composed of deformed gabbros and diorites. Sample FN25 (129 $1^{\prime} 49^{\prime \prime}$ E, $\left.42^{\circ} 41^{\prime} 57^{\prime \prime} \mathrm{N}\right)$, a diorite, was collected near Tuchengzi village, $3 \mathrm{~km}$ north to the Helong city. The rocks are deformed and consist mainly of quartz (15\%), plagioclase (70\%), biotite (10\%), and hornblende (5\%) (Figure 3A,B). Sample N-8 $\left(129^{\circ} 06^{\prime} 27^{\prime \prime} \mathrm{E}, 42^{\circ} 39^{\prime} 24^{\prime \prime} \mathrm{N}\right)$, a diorite, was collected near Bajiazi town. The rocks are slightly deformed and consist mainly of quartz $(<20 \%)$, plagioclase $(55 \%)$, biotite $(15 \%)$, and hornblende $(5 \%)$.
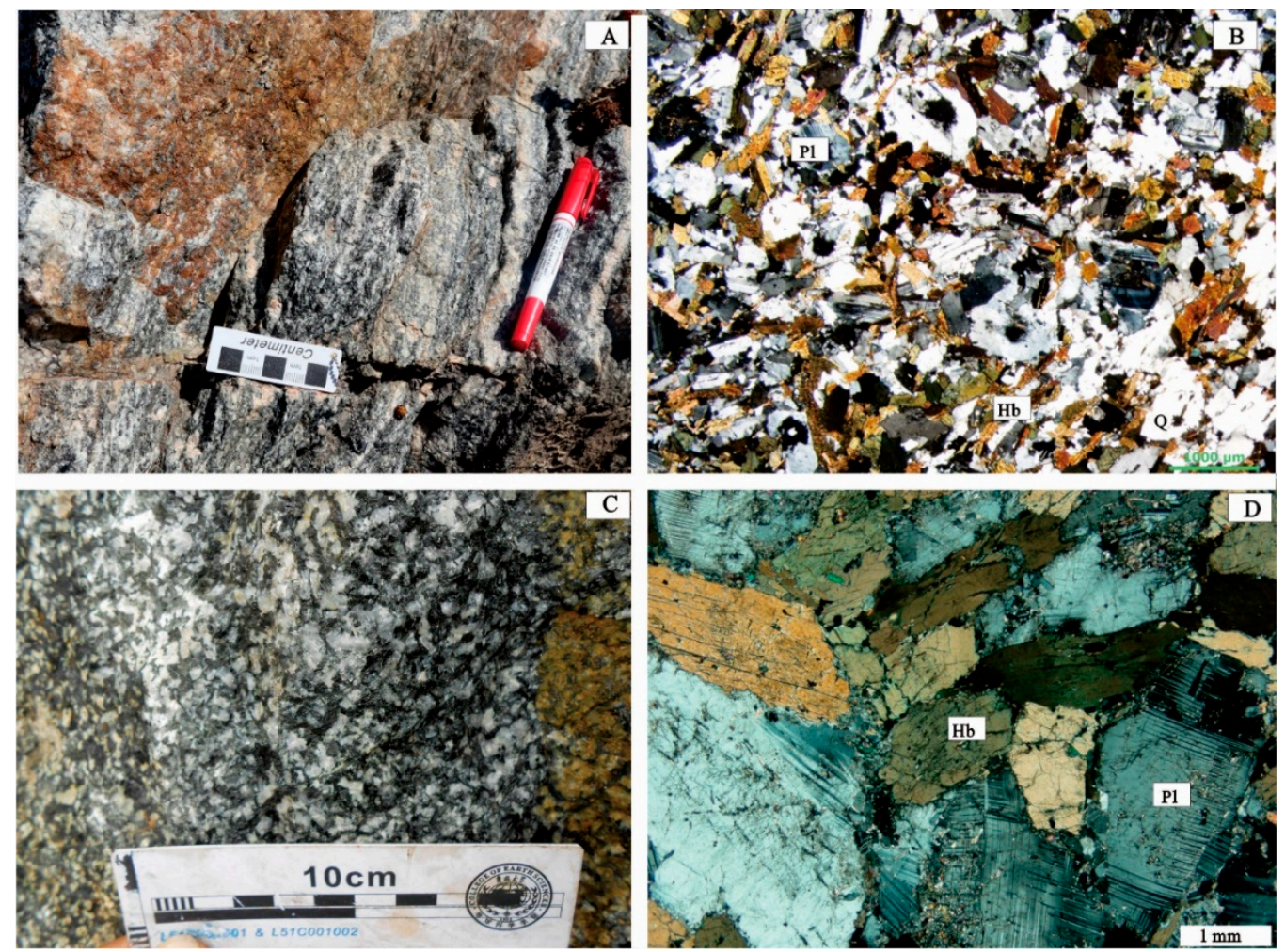

Figure 3. Outcrop-scale and microscopic features of the Late Permian diorites $(\mathbf{A}, \mathbf{B})$ and the Early Triassic hornblende-gabbros (C,D) in the study area. $\mathrm{Hb}$-hornblende, $\mathrm{Pl}$-plagiogclase, $\mathrm{Q}$ - quartz. 
The Early Triassic mafic pluton is located near the Longjing city, in the eastern part of the study area. The rocks are mainly composed of hornblende-gabbros. Sample B4117 $\left(129^{\circ} 29^{\prime} 57^{\prime \prime}\right.$ E, $\left.42^{\circ} 39^{\prime} 35^{\prime \prime} \mathrm{N}\right)$, a hornblende gabbro, was collected from Zhixingou, $5 \mathrm{~km}$ east to the Longjing City, the main minerals in the gabbroic diorite are hornblende $(40 \%)$ and plagioclase $(60 \%, \mathrm{An} \approx 65)$ (Figure 3C,D).

The Early granitic pluton is also located near the Longjing city. The rocks are mainly composed of mylonitic granitic rocks. Sample B4135 $\left(129^{\circ} 20^{\prime} 24^{\prime \prime} \mathrm{E}, 42^{\circ} 33^{\prime} 3^{\prime \prime} \mathrm{N}\right)$ is composed of plagioclase (35\%), quartz $(15 \%)$, potash feldspar (35\%), garnet (5\%), and muscovite $(5 \%)$.

\section{Analytical Methods}

\subsection{Zircon U-Pb Dating and Situ Hf Isotope Analysis}

Zircons were selected from the samples using conventional heavy liquid and magnetic techniques at the Langfang Geological Survey, Hebei province, China. Then separated grains were mounted on the resin disc under the binocular microscope and were polished to expose the grain center. The internal structures of the zircons are examined using cathodoluminescence $(\mathrm{CL})$ images prior to analysis. To determine the zircon ages, LA-ICP-MS zircon $\mathrm{U}-\mathrm{Pb}$ analyses are performed on a Neptune LA-MC-ICPMS made by Thermo Fisher Corporation with a $193 \mathrm{~nm}$ laser at Tianjin Geological Mineral Test Center, China. The spot diameter and denudation depth are $35 \mu \mathrm{m}$ and 20 to $40 \mu \mathrm{m}$, respectively. Furthermore, a zircon GJ-1 and a standard silicate glass NIST SRM610 are the standards as optimizing the analyses [39]. We corrected for common $\mathrm{Pb}$ with the method of Anderson [40]. Errors on individual analyses by LA-ICP-MS were quoted at the $1 \sigma$ level, while errors on pooled ages were quoted at the $95 \%(2 \sigma)$ confidence level.

Zircon Hf isotopic analysis in this paper were performed using a Neptune MC-ICPMS, equipped with a 193 nm laser, at Tianjin Geological Mineral Test Center, Tianjin, China. The Hf isotopic analysis was carried out at a beam density of $10-11 \mathrm{~J} / \mathrm{cm}^{2}$ and at $8-10 \mathrm{~Hz}$ with a spot sizes of $50 \mu \mathrm{m}$. Raw count rates for ${ }^{172} \mathrm{Yb},{ }^{173} \mathrm{Yb},{ }^{175} \mathrm{Lu},{ }^{176}(\mathrm{Hf}+\mathrm{Yb}+\mathrm{Lu}),{ }^{177} \mathrm{Hf},{ }^{178} \mathrm{Hf},{ }^{179} \mathrm{Hf},{ }^{180} \mathrm{Hf}$, and ${ }^{182} \mathrm{~W}$ were collected with the technique of NEPTUNE (MC-ICPMS). The detailed procedures are described by Geng et al. [41].

\subsection{Whole-Rock Elemental Analysis}

Samples are selected for whole-rock geochemical data (major and trace elements) following the removal of weathered surfaces and petrographic examination in thin sections. Fresh samples are crushed and powdered to $\sim 200$ mesh in an agate mill for whole-rock analysis. Geochemical analyses were conducted at Tianjin Geological Mineral Test Centre, and X-ray fluorescence (XRF: Rigaku RIX 2100), using fused glass beads, and ICP-MS (Agilent 7500a shield torch) were used to analyze whole-rock major and trace elements, respectively. Detailed analytical procedures for major element analysis by XRF and trace element analysis using IC-MS are described by Li, 1997 [42].

\subsection{Whole-Rock Sr-Nd Isotope Analysis}

The situ Sr-Nd isotopic analyses are conducted using a TRITON thermal ionization mass spectrometer instrument at Tianjin Geological Mineral Test Center. During the process of test, the JNdi (Nd) and NBS SRM 987 (Sr) standard were used regularly for controlling the quality and optimizing the operation parameters with the ratios of $0.512104 \pm 0.000003\left({ }^{143} \mathrm{Nd} /{ }^{144} \mathrm{Nd}\right)$ and $0.710264 \pm 0.000004$ $\left({ }^{87} \mathrm{Sr} /{ }^{86} \mathrm{Sr}\right)$, respectively [43].

\section{Analytical Results}

The LA-ICPMS zircons U-Pb data (FN25 and B4117), zircon Hf isotope data (B4117, FN25, B4135, N-8) and whole-rock major and trace elements for the intrusive rocks are listed in Tables 1 and 2, respectively. 
Table 1. Zircon U-Pb data of the Late Permian(FN25) and Early Triassic(B4117) igneous rocks in the study area.

\begin{tabular}{|c|c|c|c|c|c|c|c|c|c|c|c|c|c|c|c|}
\hline NO. & Th $\left(\times 10^{-6}\right)$ & $U\left(\times 10^{-6}\right)$ & $\mathrm{Th} / \mathrm{U}$ & ${ }^{207} \mathrm{~Pb} /{ }^{206} \mathrm{~Pb}$ & $1 \sigma$ & ${ }^{207} \mathrm{~Pb} /{ }^{235} \mathrm{U}$ & $1 \sigma$ & ${ }^{206} \mathrm{~Pb} /{ }^{238} \mathrm{U}$ & $1 \sigma$ & ${ }^{208} \mathrm{~Pb} /{ }^{232} \mathrm{Th}$ & $1 \sigma$ & ${ }^{207} \mathrm{~Pb} /{ }^{235} \mathrm{U}$ & $1 \sigma$ & ${ }^{206} \mathrm{~Pb} /{ }^{238} \mathrm{U}$ & $1 \sigma$ \\
\hline B4117.1 & 419 & 679 & 0.62 & 0.0515 & 0.0010 & 0.2827 & 0.0059 & 0.0398 & 0.0003 & 0.0084 & 0.0003 & 253 & 5 & 252 & 2 \\
\hline B4117.2 & 119 & 218 & 0.54 & 0.0595 & 0.0052 & 0.3161 & 0.0284 & 0.0385 & 0.0003 & 0.0084 & 0.0004 & 279 & 25 & 244 & 2 \\
\hline B4117.3 & 96 & 171 & 0.56 & 0.0514 & 0.0032 & 0.2784 & 0.0174 & 0.0393 & 0.0004 & 0.0092 & 0.0003 & 249 & 16 & 248 & 2 \\
\hline B4117.4 & 94 & 190 & 0.50 & 0.0524 & 0.0028 & 0.2870 & 0.0156 & 0.0397 & 0.0004 & 0.0092 & 0.0003 & 256 & 14 & 251 & 2 \\
\hline B4117.5 & 107 & 199 & 0.54 & 0.0526 & 0.0026 & 0.2857 & 0.0147 & 0.0394 & 0.0004 & 0.0092 & 0.0004 & 255 & 13 & 249 & 2 \\
\hline B4117.6 & 64 & 176 & 0.37 & 0.0527 & 0.0029 & 0.2875 & 0.0161 & 0.0396 & 0.0004 & 0.0080 & 0.0003 & 257 & 14 & 250 & 2 \\
\hline B4117.7 & 111 & 153 & 0.72 & 0.0640 & 0.0013 & 1.0229 & 0.0211 & 0.1159 & 0.0009 & 0.0260 & 0.0009 & 715 & 15 & 707 & 6 \\
\hline B4117.8 & 34 & 97 & 0.35 & 0.0520 & 0.0047 & 0.2850 & 0.0263 & 0.0398 & 0.0003 & 0.0080 & 0.0005 & 255 & 23 & 251 & 2 \\
\hline B4117.9 & 105 & 254 & 0.41 & 0.0521 & 0.0023 & 0.2818 & 0.0127 & 0.0392 & 0.0003 & 0.0105 & 0.0004 & 252 & 11 & 248 & 2 \\
\hline B4117.10 & 83 & 354 & 0.24 & 0.0514 & 0.0015 & 0.2819 & 0.0087 & 0.0397 & 0.0002 & 0.0100 & 0.0004 & 252 & 8 & 251 & 2 \\
\hline B4117.11 & 150 & 608 & 0.25 & 0.0510 & 0.0010 & 0.2839 & 0.0057 & 0.0404 & 0.0004 & 0.0115 & 0.0004 & 254 & 5 & 255 & 3 \\
\hline B4117.12 & 185 & 316 & 0.58 & 0.0513 & 0.0026 & 0.2853 & 0.0151 & 0.0403 & 0.0003 & 0.0125 & 0.0005 & 255 & 14 & 255 & 2 \\
\hline B4117.13 & 33 & 121 & 0.27 & 0.0511 & 0.0054 & 0.2836 & 0.0291 & 0.0402 & 0.0003 & 0.0130 & 0.0008 & 254 & 26 & 254 & 2 \\
\hline B4117.14 & 69 & 127 & 0.54 & 0.0515 & 0.0042 & 0.2786 & 0.0228 & 0.0393 & 0.0003 & 0.0135 & 0.0007 & 250 & 20 & 248 & 2 \\
\hline B4117.15 & 47 & 180 & 0.26 & 0.0511 & 0.0032 & 0.2823 & 0.0236 & 0.0401 & 0.0004 & 0.0152 & 0.0020 & 252 & 21 & 253 & 2 \\
\hline B4117.16 & 39 & 81 & 0.48 & 0.0511 & 0.0046 & 0.2806 & 0.0239 & 0.0398 & 0.0004 & 0.0125 & 0.0008 & 251 & 21 & 252 & 2 \\
\hline B4117.17 & 110 & 176 & 0.62 & 0.0535 & 0.0032 & 0.2894 & 0.0184 & 0.0392 & 0.0004 & 0.0140 & 0.0007 & 258 & 16 & 248 & 2 \\
\hline B4117.18 & 30 & 139 & 0.22 & 0.0548 & 0.0041 & 0.2992 & 0.0235 & 0.0396 & 0.0004 & 0.0120 & 0.0009 & 266 & 21 & 250 & 3 \\
\hline B4117.19 & 5 & 75 & 0.06 & 0.0525 & 0.0034 & 0.2885 & 0.0249 & 0.0399 & 0.0004 & 0.0480 & 0.0099 & 257 & 22 & 252 & 3 \\
\hline B4117.20 & 71 & 232 & 0.31 & 0.0493 & 0.0038 & 0.2700 & 0.0224 & 0.0398 & 0.0004 & 0.0140 & 0.0011 & 243 & 20 & 251 & 3 \\
\hline B4117.21 & 28 & 65 & 0.43 & 0.0541 & 0.0039 & 0.2982 & 0.0191 & 0.0400 & 0.0006 & 0.0190 & 0.0019 & 265 & 17 & 253 & 4 \\
\hline B4117.22 & 33 & 94 & 0.35 & 0.0534 & 0.0041 & 0.2939 & 0.0261 & 0.0399 & 0.0004 & 0.0137 & 0.0008 & 262 & 23 & 252 & 3 \\
\hline B4117.23 & 50 & 116 & 0.43 & 0.0513 & 0.0041 & 0.2841 & 0.0229 & 0.0401 & 0.0003 & 0.0102 & 0.0005 & 254 & 20 & 254 & 2 \\
\hline B4117.24 & 72 & 341 & 0.21 & 0.0542 & 0.0025 & 0.2916 & 0.0146 & 0.0390 & 0.0004 & 0.0135 & 0.0007 & 260 & 13 & 247 & 2 \\
\hline FN25.1 & 144 & 364 & 0.40 & 0.0517 & 0.0012 & 0.2981 & 0.0076 & 0.0418 & 0.0006 & 0.0124 & 0.0004 & 265 & 7 & 264 & 4 \\
\hline FN25.2 & 247 & 468 & 0.53 & 0.0526 & 0.0012 & 0.3032 & 0.0076 & 0.0418 & 0.0006 & 0.0121 & 0.0004 & 269 & 7 & 264 & 4 \\
\hline FN25.3 & 772 & 1394 & 0.55 & 0.0548 & 0.0014 & 0.3041 & 0.0087 & 0.0403 & 0.0005 & 0.0122 & 0.0003 & 270 & 8 & 254 & 3 \\
\hline FN25.4 & 301 & 709 & 0.42 & 0.0532 & 0.0008 & 0.3052 & 0.0050 & 0.0416 & 0.0005 & 0.0116 & 0.0003 & 270 & 4 & 263 & 3 \\
\hline FN25.5 & 705 & 1235 & 0.57 & 0.0539 & 0.0007 & 0.3057 & 0.0049 & 0.0411 & 0.0005 & 0.0119 & 0.0003 & 271 & 4 & 260 & 3 \\
\hline FN25.6 & 687 & 1009 & 0.68 & 0.0536 & 0.0007 & 0.3016 & 0.0045 & 0.0408 & 0.0005 & 0.0115 & 0.0003 & 268 & 4 & 258 & 3 \\
\hline FN25.7 & 387 & 678 & 0.57 & 0.0615 & 0.0011 & 0.3508 & 0.0084 & 0.0414 & 0.0005 & 0.0143 & 0.0005 & 305 & 7 & 261 & 3 \\
\hline FN25.8 & 381 & 813 & 0.47 & 0.0536 & 0.0007 & 0.3085 & 0.0048 & 0.0417 & 0.0005 & 0.0117 & 0.0004 & 273 & 4 & 263 & 3 \\
\hline FN25.9 & 150 & 297 & 0.51 & 0.0544 & 0.0016 & 0.3054 & 0.0092 & 0.0407 & 0.0004 & 0.0119 & 0.0004 & 271 & 8 & 257 & 3 \\
\hline FN25.10 & 601 & 989 & 0.61 & 0.0644 & 0.0009 & 0.3689 & 0.0065 & 0.0415 & 0.0005 & 0.0127 & 0.0004 & 319 & 6 & 262 & 3 \\
\hline
\end{tabular}


Table 1. Cont

\begin{tabular}{|c|c|c|c|c|c|c|c|c|c|c|c|c|c|c|c|}
\hline NO. & Th $\left(\times 10^{-6}\right)$ & $U\left(\times 10^{-6}\right)$ & $\mathrm{Th} / \mathrm{U}$ & ${ }^{207} \mathrm{~Pb} /{ }^{206} \mathrm{~Pb}$ & $1 \sigma$ & ${ }^{207} \mathrm{~Pb} /{ }^{235} \mathrm{U}$ & $1 \sigma$ & ${ }^{206} \mathrm{~Pb} /{ }^{238} \mathrm{U}$ & $1 \sigma$ & ${ }^{208} \mathrm{~Pb} /{ }^{232} \mathrm{Th}$ & $1 \sigma$ & ${ }^{207} \mathrm{~Pb} /{ }^{235} \mathrm{U}$ & $1 \sigma$ & ${ }^{206} \mathrm{~Pb} /{ }^{238} \mathrm{U}$ & $1 \sigma$ \\
\hline FN25.11 & 214 & 490 & 0.44 & 0.0532 & 0.0010 & 0.3049 & 0.0068 & 0.0416 & 0.0005 & 0.0114 & 0.0003 & 270 & 6 & 263 & 3 \\
\hline FN25.12 & 767 & 1381 & 0.56 & 0.0676 & 0.0016 & 0.3820 & 0.0134 & 0.0410 & 0.0007 & 0.0142 & 0.0006 & 329 & 12 & 259 & 4 \\
\hline FN25.13 & 551 & 1010 & 0.55 & 0.0539 & 0.0010 & 0.3017 & 0.0064 & 0.0406 & 0.0005 & 0.0108 & 0.0003 & 268 & 6 & 257 & 3 \\
\hline FN25.14 & 564 & 1059 & 0.53 & 0.0970 & 0.0016 & 0.5534 & 0.0105 & 0.0414 & 0.0005 & 0.0194 & 0.0006 & 447 & 9 & 261 & 3 \\
\hline FN25.15 & 840 & 1365 & 0.62 & 0.0536 & 0.0008 & 0.2960 & 0.0047 & 0.0401 & 0.0004 & 0.0099 & 0.0003 & 263 & 4 & 253 & 3 \\
\hline FN25.16 & 636 & 1226 & 0.52 & 0.0509 & 0.0006 & 0.2570 & 0.0037 & 0.0366 & 0.0004 & 0.0094 & 0.0004 & 232 & 3 & 232 & 3 \\
\hline FN25.17 & 359 & 1134 & 0.32 & 0.0667 & 0.0012 & 0.3439 & 0.0067 & 0.0374 & 0.0004 & 0.0107 & 0.0004 & 300 & 6 & 237 & 3 \\
\hline FN25.18 & 347 & 682 & 0.51 & 0.0535 & 0.0007 & 0.3019 & 0.0046 & 0.0409 & 0.0005 & 0.0098 & 0.0003 & 268 & 4 & 259 & 3 \\
\hline FN25.19 & 1645 & 1704 & 0.97 & 0.0792 & 0.0011 & 0.4236 & 0.0064 & 0.0388 & 0.0004 & 0.0094 & 0.0002 & 359 & 5 & 245 & 3 \\
\hline FN25.20 & 75 & 1186 & 0.06 & 0.0525 & 0.0007 & 0.2953 & 0.0050 & 0.0408 & 0.0005 & 0.0092 & 0.0002 & 263 & 4 & 258 & 3 \\
\hline
\end{tabular}

Table 2. Hf isotopic data of zircons extracted from the Late Permian and Early Triassic igneous rocks in the study area.

\begin{tabular}{|c|c|c|c|c|c|c|c|c|c|c|c|c|c|}
\hline No. & Age (Ma) & ${ }^{176} \mathrm{Yb} /{ }^{177} \mathrm{Hf}$ & & ${ }^{176} \mathrm{Lu} /{ }^{177} \mathrm{Hf}$ & & ${ }^{176} \mathrm{Hf} /{ }^{177} \mathrm{Hf}$ & & ${ }^{176} \mathrm{Hf} /{ }^{177} \mathrm{Hf}_{\mathrm{i}}$ & $\mathbf{e}_{\mathrm{Hf}}(\mathbf{0})$ & $\mathbf{e}_{\mathrm{Hf}}(\mathbf{t})$ & $\mathrm{T}_{\mathrm{DM}}(\mathrm{Ma})$ & $\mathrm{T}_{\mathrm{DM}}^{\mathrm{C}}(\mathrm{Ma})$ & $\mathrm{f}_{\mathrm{Lu} / \mathrm{Hf}}$ \\
\hline B4117.1 & 252 & 0.0348 & 0.0001 & 0.0014 & 0.0000 & 0.282836 & 0.000023 & 0.282830 & 2.3 & 7.6 & 596 & 1022 & -0.96 \\
\hline B4117.2 & 244 & 0.0118 & 0.0001 & 0.0005 & 0.0000 & 0.282869 & 0.000021 & 0.282867 & 3.4 & 8.7 & 536 & 914 & -0.99 \\
\hline B4117.3 & 248 & 0.0139 & 0.0001 & 0.0005 & 0.0000 & 0.282854 & 0.000016 & 0.282851 & 2.9 & 8.2 & 559 & 958 & -0.98 \\
\hline B4117.4 & 251 & 0.0142 & 0.0001 & 0.0005 & 0.0000 & 0.282922 & 0.000017 & 0.282919 & 5.3 & 10.7 & 463 & 735 & -0.98 \\
\hline B4117.5 & 249 & 0.0118 & 0.0001 & 0.0004 & 0.0000 & 0.282838 & 0.000016 & 0.282836 & 2.3 & 7.7 & 579 & 1006 & -0.99 \\
\hline B4117.6 & 250 & 0.0112 & 0.0000 & 0.0005 & 0.0000 & 0.282849 & 0.000020 & 0.282847 & 2.7 & 8.2 & 564 & 968 & -0.99 \\
\hline B4117.8 & 251 & 0.0070 & 0.0001 & 0.0003 & 0.0000 & 0.282839 & 0.000018 & 0.282838 & 2.4 & 7.9 & 575 & 996 & -0.99 \\
\hline B4117.9 & 248 & 0.0148 & 0.0001 & 0.0006 & 0.0000 & 0.282916 & 0.000018 & 0.282913 & 5.1 & 10.4 & 472 & 760 & -0.98 \\
\hline B4117.10 & 251 & 0.0116 & 0.0002 & 0.0005 & 0.0000 & 0.282882 & 0.000018 & 0.282879 & 3.9 & 9.3 & 519 & 864 & -0.98 \\
\hline B4135.2 & 252 & 0.0177 & 0.0005 & 0.0008 & 0.0000 & 0.282639 & 0.000019 & 0.282635 & -4.7 & 0.7 & 865 & 1644 & -0.97 \\
\hline B4135.3 & 253 & 0.0086 & 0.0001 & 0.0004 & 0.0000 & 0.282628 & 0.000017 & 0.282626 & -5.1 & 0.4 & 870 & 1670 & -0.99 \\
\hline B4135.4 & 254 & 0.0230 & 0.0003 & 0.0010 & 0.0000 & 0.282630 & 0.000017 & 0.282626 & -5.0 & 0.4 & 881 & 1671 & -0.97 \\
\hline B4135.6 & 253 & 0.0170 & 0.0001 & 0.0008 & 0.0000 & 0.282661 & 0.000015 & 0.282658 & -3.9 & 1.5 & 833 & 1571 & -0.98 \\
\hline B4135.7 & 247 & 0.0116 & 0.0001 & 0.0006 & 0.0000 & 0.282618 & 0.000013 & 0.282615 & -5.5 & -0.1 & 889 & 1713 & -0.98 \\
\hline B4135.8 & 252 & 0.0122 & 0.0003 & 0.0006 & 0.0000 & 0.282661 & 0.000012 & 0.282659 & -3.9 & 1.5 & 828 & 1568 & -0.98 \\
\hline B4135.9 & 253 & 0.0210 & 0.0003 & 0.0009 & 0.0000 & 0.282573 & 0.000014 & 0.282569 & -7.0 & -1.6 & 959 & 1854 & -0.97 \\
\hline B4135.10 & 251 & 0.0087 & 0.0002 & 0.0004 & 0.0000 & 0.282885 & 0.000015 & 0.282883 & 4.0 & 9.4 & 513 & 852 & -0.99 \\
\hline B4135.12 & 255 & 0.0525 & 0.0006 & 0.0019 & 0.0000 & 0.282488 & 0.000016 & 0.282479 & -10.0 & -4.8 & 1108 & 2136 & -0.94 \\
\hline B4135.13 & 253 & 0.0060 & 0.0000 & 0.0003 & 0.0000 & 0.282668 & 0.000015 & 0.282666 & -3.7 & 1.8 & 813 & 1543 & -0.99 \\
\hline
\end{tabular}


Table 2. Cont.

\begin{tabular}{|c|c|c|c|c|c|c|c|c|c|c|c|c|c|}
\hline No. & Age (Ma) & ${ }^{176} \mathrm{Yb} /{ }^{177} \mathrm{Hf}$ & & ${ }^{176} \mathrm{Lu} /{ }^{177} \mathrm{Hf}$ & & ${ }^{176} \mathrm{Hf} /{ }^{177} \mathrm{Hf}$ & & ${ }^{176} \mathrm{Hf} /{ }^{177} \mathbf{H f}_{\mathbf{i}}$ & $\mathbf{e}_{\mathrm{Hf}}(\mathbf{0})$ & $\mathbf{e}_{\mathrm{Hf}}(\mathbf{t})$ & $\mathrm{T}_{\mathrm{DM}}(\mathrm{Ma})$ & $\mathrm{T}_{\mathrm{DM}}{ }^{\mathrm{C}}(\mathrm{Ma})$ & $\mathrm{f}_{\mathrm{Lu} / \mathrm{H} \mathrm{I}}$ \\
\hline N8.1 & 257 & 0.0150 & 0.0008 & 0.0006 & 0.0000 & 0.282669 & 0.000017 & 0.282666 & -3.6 & 1.9 & 819 & 1539 & -0.98 \\
\hline $\mathrm{N} 8.2$ & 259 & 0.0133 & 0.0006 & 0.0006 & 0.0000 & 0.282697 & 0.000017 & 0.282694 & -2.6 & 2.9 & 778 & 1445 & -0.98 \\
\hline N8.3 & 259 & 0.0281 & 0.0009 & 0.0010 & 0.0000 & 0.282652 & 0.000021 & 0.282647 & -4.2 & 1.3 & 851 & 1596 & -0.97 \\
\hline N8.5 & 259 & 0.0167 & 0.0002 & 0.0007 & 0.0000 & 0.282656 & 0.000015 & 0.282653 & -4.1 & 1.5 & 838 & 1578 & -0.98 \\
\hline N8.6 & 257 & 0.0314 & 0.0011 & 0.0012 & 0.0000 & 0.282644 & 0.000019 & 0.282638 & -4.5 & 0.9 & 867 & 1628 & -0.96 \\
\hline N8.7 & 257 & 0.0196 & 0.0004 & 0.0007 & 0.0000 & 0.282720 & 0.000018 & 0.282716 & -1.8 & 3.7 & 749 & 1377 & -0.98 \\
\hline N8.8 & 259 & 0.0227 & 0.0002 & 0.0009 & 0.0000 & 0.282672 & 0.000016 & 0.282668 & -3.5 & 2.0 & 819 & 1530 & -0.97 \\
\hline N8.10 & 258 & 0.0228 & 0.0003 & 0.0009 & 0.0000 & 0.282669 & 0.000013 & 0.282665 & -3.6 & 1.9 & 825 & 1541 & -0.97 \\
\hline N8.19 & 259 & 0.0260 & 0.0007 & 0.0010 & 0.0000 & 0.282629 & 0.000020 & 0.282624 & -5.1 & 0.5 & 882 & 1669 & -0.97 \\
\hline N8.22 & 257 & 0.0258 & 0.0008 & 0.0010 & 0.0000 & 0.282665 & 0.000017 & 0.282660 & -3.8 & 1.7 & 832 & 1558 & -0.97 \\
\hline N8.23 & 259 & 0.0232 & 0.0003 & 0.0010 & 0.0000 & 0.282690 & 0.000020 & 0.282685 & -2.9 & 2.6 & 796 & 1474 & -0.97 \\
\hline FN25.21 & 258 & 0.0665 & 0.0032 & 0.0020 & 0.0001 & 0.282867 & 0.000038 & 0.282858 & 3.4 & 8.7 & 561 & 924 & -0.94 \\
\hline FN25.1 & 264 & 0.0186 & 0.0004 & 0.0005 & 0.0000 & 0.282880 & 0.000032 & 0.282877 & 3.8 & 9.5 & 521 & 853 & -0.99 \\
\hline FN25.2 & 264 & 0.0372 & 0.0042 & 0.0011 & 0.0001 & 0.282882 & 0.000032 & 0.282876 & 3.9 & 9.5 & 526 & 856 & -0.97 \\
\hline FN25.3 & 254 & 0.0598 & 0.0012 & 0.0018 & 0.0000 & 0.282807 & 0.000029 & 0.282799 & 1.2 & 6.5 & 645 & 1118 & -0.95 \\
\hline FN25.4 & 263 & 0.0246 & 0.0011 & 0.0008 & 0.0000 & 0.282804 & 0.000026 & 0.282801 & 1.1 & 6.8 & 631 & 1100 & -0.98 \\
\hline FN25.8 & 263 & 0.0378 & 0.0003 & 0.0011 & 0.0000 & 0.282869 & 0.000024 & 0.282864 & 3.4 & 9.0 & 545 & 898 & -0.97 \\
\hline FN25.9 & 257 & 0.0394 & 0.0010 & 0.0011 & 0.0000 & 0.282765 & 0.000027 & 0.282760 & -0.2 & 5.2 & 691 & 1237 & -0.97 \\
\hline FN25.13 & 257 & 0.0378 & 0.0004 & 0.0012 & 0.0000 & 0.282840 & 0.000027 & 0.282834 & 2.4 & 7.8 & 588 & 1002 & -0.96 \\
\hline FN25.15 & 253 & 0.0550 & 0.0005 & 0.0016 & 0.0000 & 0.282881 & 0.000025 & 0.282873 & 3.9 & 9.1 & 536 & 881 & -0.95 \\
\hline FN25.19 & 259 & 0.0310 & 0.0012 & 0.0009 & 0.0000 & 0.282821 & 0.000024 & 0.282816 & 1.7 & 7.3 & 610 & 1055 & -0.97 \\
\hline
\end{tabular}




\subsection{LA-ICPMS Zircon U-Pb Ages}

Sample FN25 and B4117 are collected for zircon LA-ICP-MS dating in the study area. CL images of the representative zircons and zircons data are presented in Figure 4.
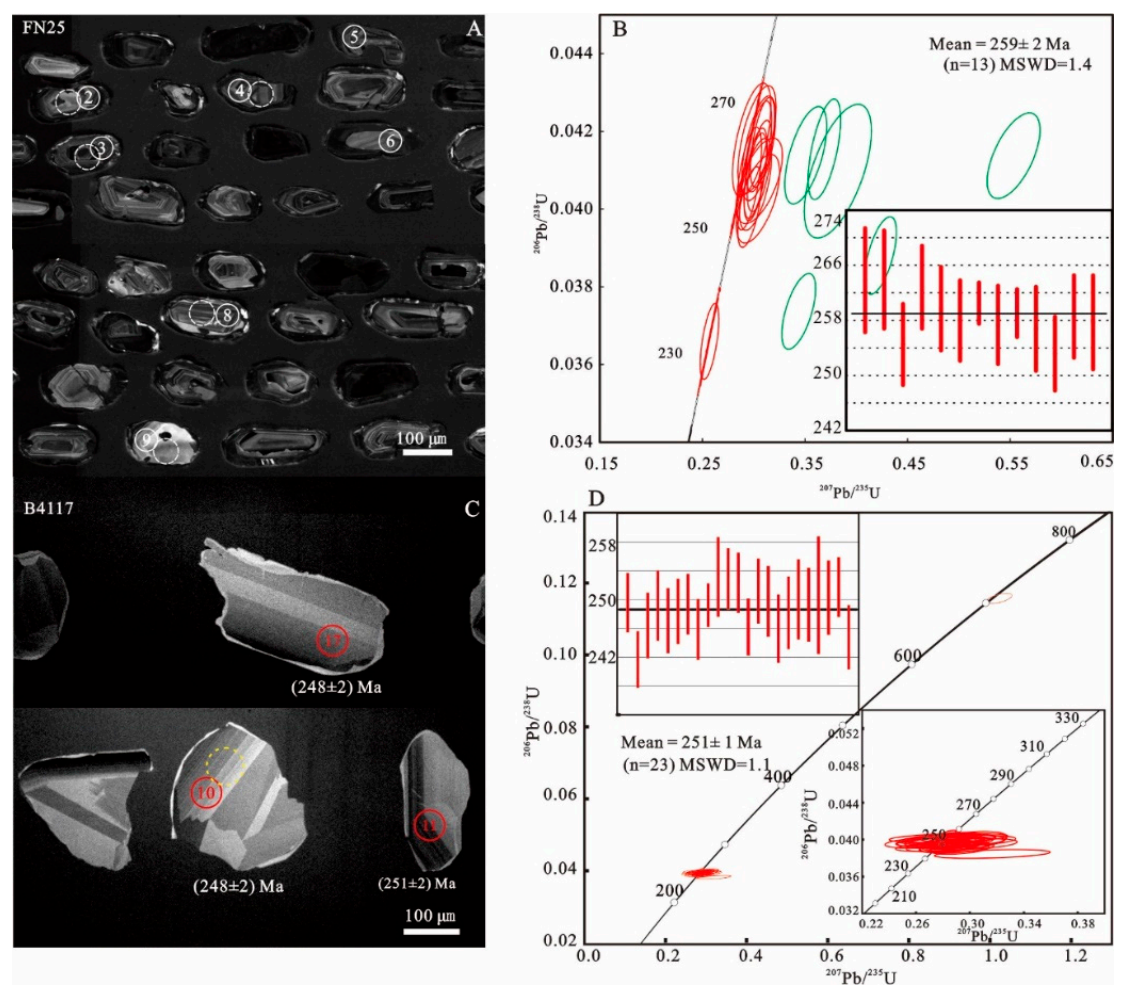

Figure 4. $\mathrm{CL}$ images of the zircons and zircon $\mathrm{U}-\mathrm{Pb}$ Concordia diagrams and weighted mean ages from the quartz diorite (FN25, (A,B)) and hornblende gabbro (B4117, (C,D)) in the study area. The circles that represent dating ages in red are for the weighted mean age while the circles in green are not for the weighted mean age due to the Pb loss.

\subsubsection{Quartz Diorite (Sample FN25)}

Twenty zircons from FN25 are generally euhedral-subhedral in shape and have the length ranging from $100 \mu \mathrm{m}$ to $200 \mu \mathrm{m}$, while the length to width ratios are from 2:1 to 3:1. CL analyses reveal that most zircons have fine-scale oscillatory growth zoning, showing the features of the magmatic-like zircons (Figure 4A). In addition, they all have the high Th/U ratios (0.32-0.97) except one (spot 20) with 0.06 , and most of them show magmatic-like zircon characteristics. A total of 20 spots were analyzed on 20 zircons from sample FN25, and their ${ }^{206} \mathrm{~Pb} /{ }^{238} \mathrm{U}$ ages mainly range from $253 \mathrm{Ma}$ to $264 \mathrm{Ma}$; however, three younger zircons with a ${ }^{206} \mathrm{~Pb} /{ }^{238} \mathrm{U}$ age of $232 \mathrm{Ma}, 237 \mathrm{Ma}$, and $245 \mathrm{Ma}$. Thirteen spots yield a weighted mean age of $259 \pm 2 \mathrm{Ma}(\mathrm{MSWD}=1.4, \mathrm{n}=13$ ) (Figure $4 \mathrm{~B}$ ). This age is from zircons with oscillatory growth zoning; thus interpreted as the crystallization age of the quartz diorite. Furthermore, this age is also consistent with the age of sample N-8 (257 Ma) in Guan et al. [34].

\subsubsection{Hornblende Gabbro (Sample B4117)}

Twenty-four zircons from B4117 are slightly rounded and generally fractured in shape. They have the length ranging from $120 \mu \mathrm{m}$ to $200 \mu \mathrm{m}$, with length/width ratios of 1:1-2:1. CL images show that most zircons have banded texture, and a few zircons have fine-scale oscillatory growth zoning (Figure $4 \mathrm{C}$ ), in addition, the $\mathrm{Th} / \mathrm{U}$ ratios are from 0.06 to 0.72 . The features mentioned above are similar with the features of the basaltic magmatic-like zircons. Twenty-four analyses were made on 24 zircons and have ${ }^{206} \mathrm{~Pb} /{ }^{238} \mathrm{U}$ ages ranging from $244 \pm 2 \mathrm{Ma}$ to $707 \pm 6 \mathrm{Ma}$. Twenty-three analyses ranging from $244 \pm 2$ Ma to $255 \pm 2$ Ma have a weighted mean age of $251 \pm 1 \mathrm{Ma}(\mathrm{MSWD}=1.1, \mathrm{n}=23$ ) (Figure 4D); 
however, magmatic-like zircons indicate that the age of $251 \pm 1$ Ma represents the protolith age of the hornblende gabbros. One spot yields a Concordia age of $707 \pm 6 \mathrm{Ma}$, interpreted as the crystallization age of a xenocrystic zircon inherited in the hornblende gabbro.

\subsection{Zircon Hf Isotopic Compositions}

A total of 40 zircon ages from four samples (FN25, B4117, B4135-2 (the sample dating age is reported by Shi et al., 2013 [44]), and N-8 (the sample dating age is reported by Guan et al., 2016 [35]) is used for $\mathrm{Hf}$ isotope analyses. The $\varepsilon \mathrm{Hf}(\mathrm{t})$ for magmatic zircons with ages of 244-264 Ma are between -4.8 and +10.7 . Their corresponding initial ${ }^{176} \mathrm{Hf} /{ }^{177} \mathrm{Hf}$ and $\mathrm{T}_{\mathrm{DM} 1}$ values vary from 0.282479 to 0.282922 , and from $463 \mathrm{Ma}$ to $1108 \mathrm{Ma}$, respectively (Table 2).

Ten zircons from sample FN25 are dated for $\mathrm{Hf}$ isotopic compositions, with ${ }^{176} \mathrm{Hf} /{ }^{177} \mathrm{Hf}$ ratios of $0.282765-0.282882, \varepsilon H f(t)$ values of +5.2 to +9.5 , $\mathrm{T}_{\mathrm{DM} 1}$ values of $521-691 \mathrm{Ma}$, and $\mathrm{T}_{\mathrm{DM} 2}$ values of 853-1237 Ma, respectively.

Eleven zircons from $\mathrm{N}-8$ were dated for $\mathrm{Hf}$ isotopic compositions, with ${ }^{176} \mathrm{Hf} /{ }^{177} \mathrm{Hf}$ ratios of $0.282624-0.282726, \varepsilon \mathrm{Hf}(\mathrm{t})$ values of +0.5 to $+3.7, \mathrm{~T}_{\mathrm{DM} 1}$ values of $749-882 \mathrm{Ma}$, and $\mathrm{T}_{\mathrm{DM} 2}$ values of 1377-1669 Ma, respectively.

Zircon Hf spot analyses from sample B4117 were obtained. The initial ${ }^{176} \mathrm{Hf} /{ }^{177} \mathrm{Hf}$ ratios are from nine zircons varying from 244 to $252 \mathrm{Ma}$, with values of $0.282830-0.282919$. Their $\varepsilon \mathrm{Hf}(\mathrm{t})$ values range from +7.6 to +10.7 , with $\mathrm{T}_{\mathrm{DM} 1}$ age between $463 \mathrm{Ma}$ and $596 \mathrm{Ma}$ and $\mathrm{T}_{\mathrm{DM} 2}$ age between $735 \mathrm{Ma}$ and $1022 \mathrm{Ma}$.

Zircon Hf spot analyses from sample B4135 were obtained. The initial ${ }^{176} \mathrm{Hf} /{ }^{177} \mathrm{Hf}$ ratios are from ten zircons varying from $247 \mathrm{Ma}$ to $255 \mathrm{Ma}$, with values of $0.282479-0.282883$. Their $\varepsilon \mathrm{Hf}(\mathrm{t})$ values range from -4.8 to +9.4 , with $\mathrm{T}_{\mathrm{DM} 1}$ age between $513 \mathrm{Ma}$ and $1108 \mathrm{Ma}$ and $\mathrm{T}_{\mathrm{DM} 2}$ age between $852 \mathrm{Ma}$ and $2136 \mathrm{Ma}$.

All the analyzed zircons have Hf isotopic compositions that are similar with those of Phanerozoic igneous rocks in the East CAOB (Figure 5).

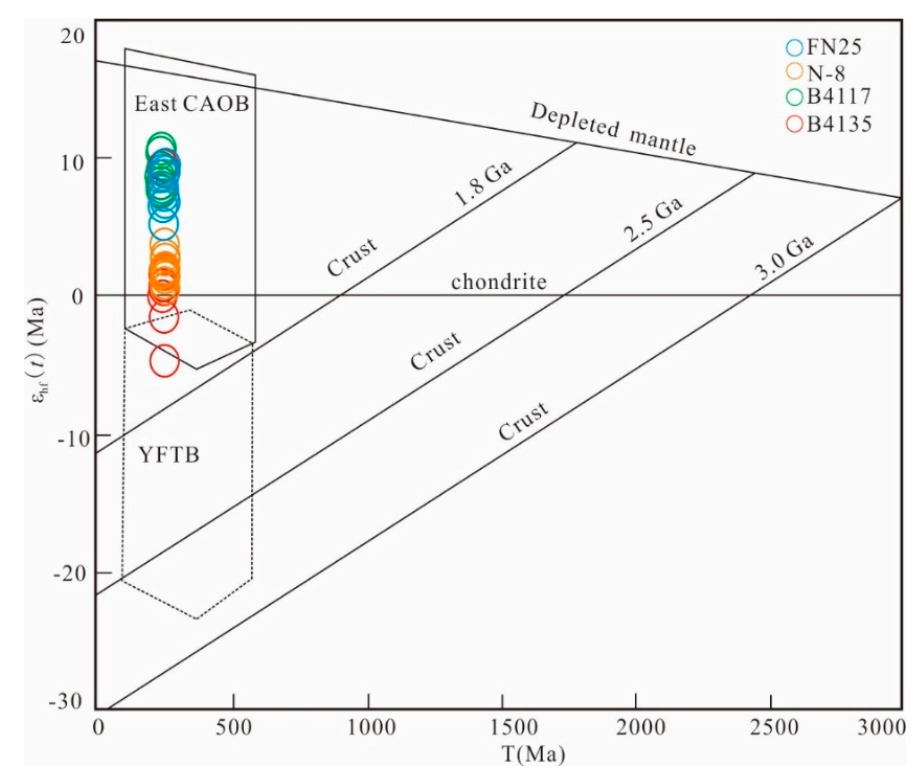

Figure 5. $\varepsilon_{\mathrm{Hf}}(\mathrm{t})$ versus diagram of the intrusive rocks in this study. CAOB: Central Asian Orogenic Belt; YFTB: Yanshan Fold and Thrust Belt (Yang et al., 2006 [45]).

\subsection{Major and Trace Elements}

Four samples, listed in Table 3, are analyzed to know the geochemical features of the Early Triassic mafic plutonic rocks in the study area. The geochemical data of Late Permian diorites and Early Triassic granites are from Guan et al. [34] and Shi et al. [44]. All the data are plotted in Figures 6 and 7. 

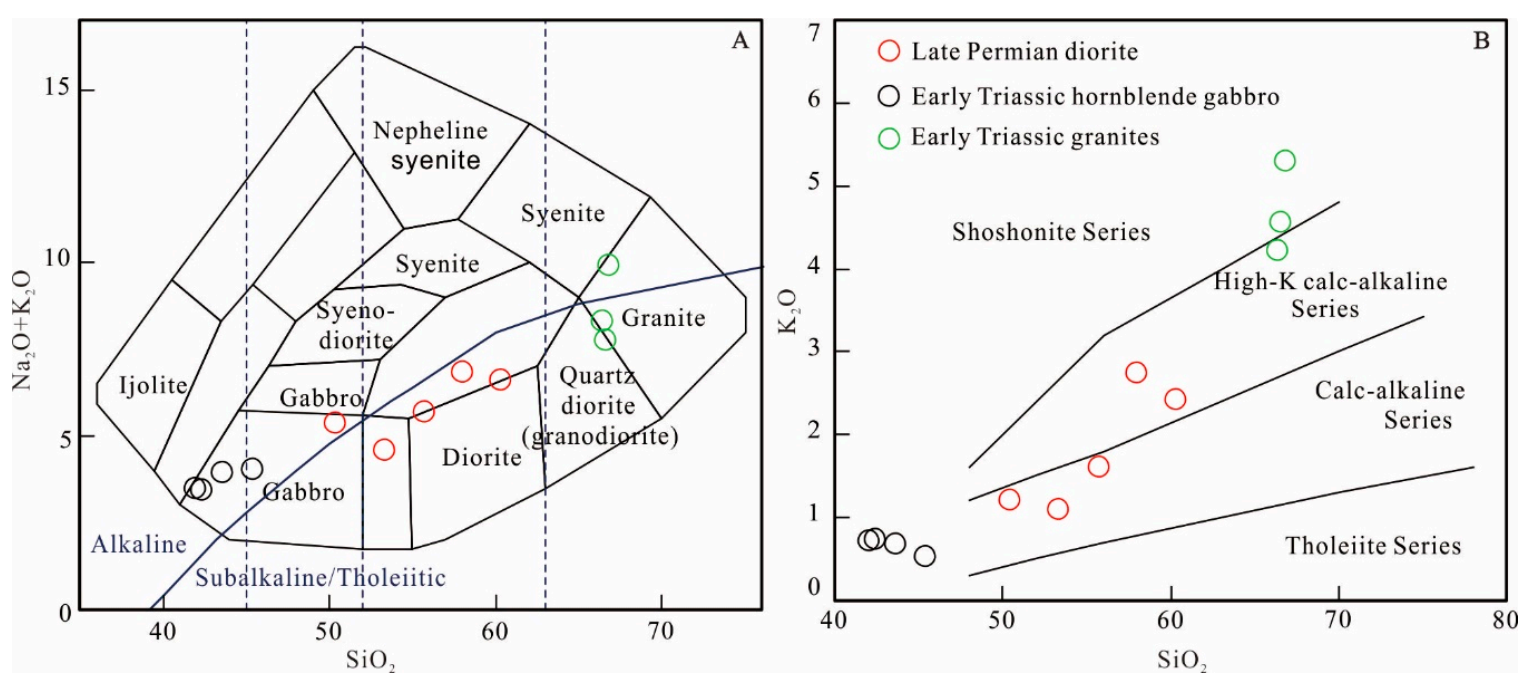

Figure 6. TAS (A), modified after Irvine and Baragar [46] and $\mathrm{SiO}_{2}-\mathrm{K}_{2} \mathrm{O}(\mathbf{B})$, modified after Peccerillo and Taylor [47] diagrams of the Late Permian diorite and the Early Triassic intrusive rocks in the Yanbian area.

The diorite has the content of $\mathrm{SiO}_{2}, \mathrm{Al}_{2} \mathrm{O}_{3}, \mathrm{TiO}_{2}, \mathrm{~K}_{2} \mathrm{O}$, and $\mathrm{Na}_{2} \mathrm{O}$, ranging from $50.40 \%$ to $60.30 \%$, from $17.00 \%$ to $19.60 \%$, from $1.01 \%$ to $1.53 \%$, from $1.09 \%$ to $2.74 \%$, and from $3.50 \%$ to $4.20 \%$, respectively. However, the samples are plotted in the subalkaline field in the TAS diagram (Figure 6A). In the $\mathrm{SiO}_{2}-\mathrm{K}_{2} \mathrm{O}$ diagram, the samples are plotted in the calc alkaline to high- $\mathrm{K}$ calc alkaline series (Figure 6B). The samples are enriched in LREEs, depleted in HREEs and the Eu anomalies are from 0.57 to 1.35 (Figure 7A); however, the Eu anomalies of some samples are negative while the Eu anomalies of other samples are positive [34]. On the PM (primitive-mantle) normalized trace element spidergrams (Figure 7B), the rocks are enriched in large ion lithophile elements (LILEs, such as CS, Ba, K, and Sr), but are depleted in high-field strength elements (HFSEs, such as $\mathrm{Nb}, \mathrm{Ta}, \mathrm{P}$, and Ti) and $\mathrm{Ba}$.

The mylonitic granites were divided into two groups according to the content of $\mathrm{SiO}_{2}$ in $\mathrm{Guan}_{\text {et al., }}$ 2016 [35]. However, because of the existence of $\sim 190 \mathrm{Ma}$ zircons in the Triassic sample $\mathrm{P}_{4} \mathrm{~B}_{16-2}$ [34] with high $\mathrm{SiO}_{2}(>70.00 \%)$, the samples with high $\mathrm{SiO}_{2}(>70.00 \%)$ are not likely to represent the geochemical features of the Early Triassic mylonitic granites. Thereby, we have the opinion that the samples with low $\mathrm{SiO}_{2}(<70.00 \%)$ could represent the geochemical features of the Early Triassic mylonitic granites. The mylonitic granite samples span a narrow $\mathrm{SiO}_{2}$ range of $66.4 \%$ and $66.8 \%$, and the content of $\mathrm{Al}_{2} \mathrm{O}_{3}, \mathrm{~K}_{2} \mathrm{O}+\mathrm{Na}_{2} \mathrm{O}$, and $\mathrm{TiO}_{2}$ range from $14.5 \%$ to $16.3 \%$, from $7.74 \%$ to $9.92 \%$, and from $0.51 \%$ to $0.73 \%$, respectively. The geochemical features imply that the samples have an affinity to geochemical characteristics of shoshonitic rocks [48,49]. Furthermore, the ratios of $\mathrm{Fe}_{2} \mathrm{O}_{3} / \mathrm{FeO}$ (0.57-1.29) and $\mathrm{K}_{2} \mathrm{O} / \mathrm{Na}_{2} \mathrm{O}$ (1.03-1.43) also show the geochemical characteristics of the shoshonitic rocks [48]. Most samples are plotted in the shoshonite field in the $\mathrm{SiO}_{2}-\mathrm{K}_{2} \mathrm{O}$ diagram (Figure 6B). These samples display slightly LREE-enriched patterns with negative or no Eu anomalies (Figure 7A). On the PM (primitive-mantle) normalized trace element spidergrams (Figure 7B), the rocks are enriched in LILEs, such as $\mathrm{Cs}, \mathrm{Rb}$, and $\mathrm{K}$. The depletion of $\mathrm{Ta}, \mathrm{Nb}$, and $\mathrm{Ti}$ (TNT) also shows the characteristics of the shoshonitic rocks.

The Early Triassic hornblende gabbros have a low content of $\mathrm{SiO}_{2}$ ranging from $42.00 \%$ to $45.42 \%$, intermediary contents of $\mathrm{Na}_{2} \mathrm{O}+\mathrm{K}_{2} \mathrm{O}$ ranging from $3.44 \%$ to $4.03 \%$ and high contents of $\mathrm{Al}_{2} \mathrm{O}_{3}$ ranging from $16.20 \%$ to $19.86 \%$. The $\mathrm{MgO}, \mathrm{Fe}_{2} \mathrm{O}_{3}, \mathrm{FeO}$, and $\mathrm{TiO}_{2}$ range from $4.73 \%$ to $7.46 \%$, from $5.41 \%$ to $14.57 \%, 7.26 \%$ to $9.27 \%$, and from $1.50 \%$ to $2.24 \%$, respectively. In the TAS diagram (Figure $6 \mathrm{~A}$ ), the gabbros show alkaline features. With increasing $\mathrm{MgO}$ and $\mathrm{Ni}$ contents $\mathrm{SiO}_{2}, \mathrm{Al}_{2} \mathrm{O}_{3}$, and $\mathrm{CaO}$ decrease (Figure 8). Additionally, the concentrations of $\mathrm{V}$ increase with the increasing of $\mathrm{TiO}_{2}$ (Figure $8 \mathrm{~F}$ ). All the samples display slightly LREE-enriched patterns $\left((\mathrm{La} / \mathrm{Yb})_{\mathrm{N}}=4.12-7.61\right)$ with negligible to positive Eu anomalies $(\mathrm{Eu}=0.97-1.17)$ (Figure 7A). On the PM (primitive-mantle) normalized trace 
element spidergrams (Figure 7B), the rocks are enriched in large ion lithophile elements (LILEs, such as $\mathrm{Cs}, \mathrm{Ba}, \mathrm{K}$, and $\mathrm{Sr}$ ), but are depleted in high field strength elements (HFSE, such as $\mathrm{Nb}, \mathrm{Ta}$, and $\mathrm{Zr}$ ).

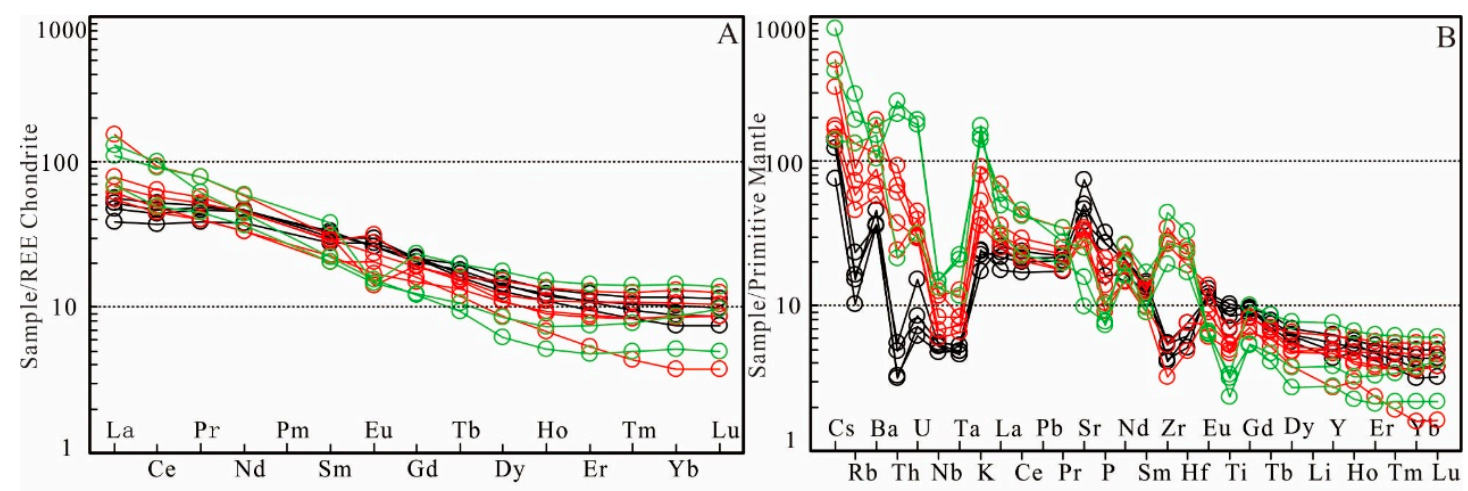

Figure 7. Chondrite-normalized REE patterns (A) and primitive mantle-normalized trace element spidergrams (B) for the Late Permian diorite and gabbro and the Early Triassic intrusive rocks in the Yanbian area. Normalizing values of chondrite and of primitive mantle are from Boynton [50] and Sun and McDonough [51].
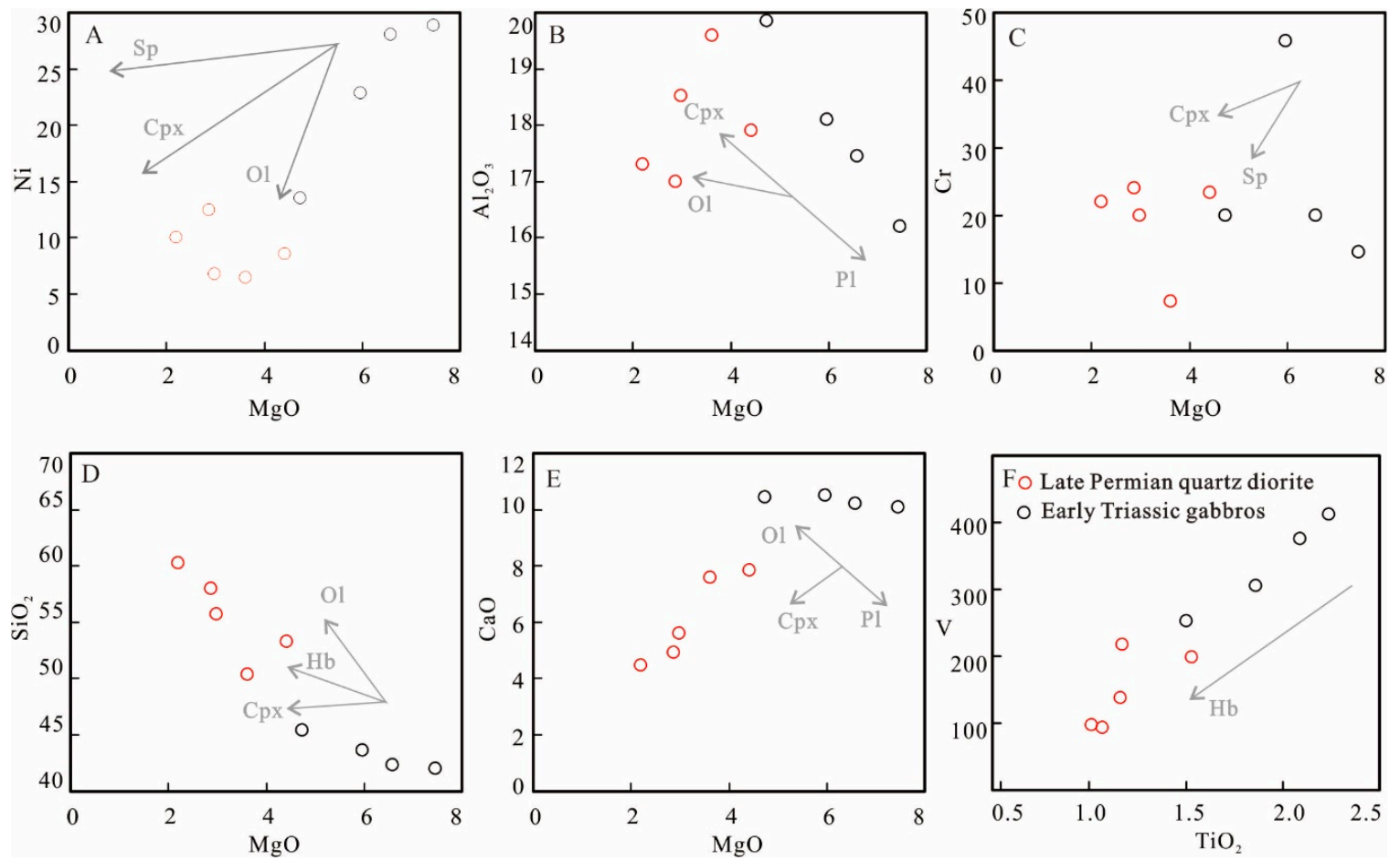

Figure 8. Harker diagrams of the Late Permian diorite and Early Triassic gabbro samples. (A) Ni, (B) $\mathrm{Al}_{2} \mathrm{O}_{3},(\mathbf{C}) \mathrm{Cr},\left(\right.$ D) $\mathrm{SiO}_{2}$, (E) $\mathrm{CaO}$, versus $\mathrm{MgO}$, and (F) V versus $\mathrm{TiO}_{2}$.

\subsection{Sr-Nd Isotopic Analyses}

The whole-rock Sr-Nd isotopic analyses are listed in Table 4 . The initial ${ }^{87} \mathrm{Sr} /{ }^{86} \mathrm{Sr}$ and $\varepsilon \mathrm{Nd}(\mathrm{t})$ isotopic compositions were calculated at $t=251 \mathrm{Ma}$. For the Early Triassic gabbros, $\left({ }^{87} \mathrm{Sr} /{ }^{86} \mathrm{Sr}\right)_{\mathrm{i}}=0.70376-0.70499$ and $\varepsilon \mathrm{Nd}(\mathrm{t})=+0.7$ to +3.4 , and the $\mathrm{Nd}$ model ages $\left(\mathrm{T}_{\mathrm{DM} 1}\right.$ and $\left.\mathrm{T}_{\mathrm{DM} 2}\right)$ range from 1032 to $1005 \mathrm{Ma}$, and from 963 to $743 \mathrm{Ma}$, respectively. These values are consistent with those of the Phanerozoic granitoids in the CAOB $[52,53]$. 
Table 3. Chemical compositions of major elements $(\mathrm{wt} \%)$ and trace elements $\left(\times 10^{-6}\right)$ of the Late Permian diorite and gabbro and the Early Triassic intrusive rocks.

\begin{tabular}{|c|c|c|c|c|c|c|c|c|c|c|c|c|}
\hline Sample & B4117-1 & B4117-2 & Yh59-2 & Yh59-3 & Dh034 & Dh041 & $1245-1$ & $\mathrm{~N}-8$ & B4396-1 & 4119-1 & YH34 & 4134-1 \\
\hline $\mathrm{SiO}_{2}$ & 42 & 43.6 & 45.42 & 42.36 & 60.3 & 50.4 & 53.3 & 58.0 & 55.7 & 66.8 & 66.4 & 66.6 \\
\hline $\mathrm{Al}_{2} \mathrm{O}_{3}$ & 16.2 & 18.1 & 19.86 & 17.46 & 17.3 & 19.6 & 17.9 & 17.0 & 18.5 & 16.3 & 15.8 & 14.5 \\
\hline $\mathrm{Fe}_{2} \mathrm{O}_{3}$ & 6.92 & 5.41 & 11.53 & 14.57 & 2.33 & 3.86 & 3.62 & 0.99 & 2.30 & 1.10 & 2.19 & 1.63 \\
\hline $\mathrm{FeO}$ & 8.6 & 7.7 & 7.26 & 9.67 & 3.82 & 6.05 & 5.43 & 6.41 & 5.12 & 1.85 & 1.70 & 2.93 \\
\hline $\mathrm{CaO}$ & 10.1 & 10.5 & 10.44 & 10.23 & 4.47 & 7.58 & 7.85 & 4.94 & 5.60 & 1.64 & 2.38 & 3.01 \\
\hline $\mathrm{MgO}$ & 7.46 & 5.96 & 4.73 & 6.57 & 2.20 & 3.62 & 4.42 & 2.86 & 2.98 & 0.81 & 0.95 & 1.65 \\
\hline $\mathrm{K}_{2} \mathrm{O}$ & 0.72 & 0.68 & 0.52 & 0.73 & 2.41 & 1.21 & 1.09 & 2.74 & 1.61 & 5.30 & 4.22 & 4.56 \\
\hline $\mathrm{Na}_{2} \mathrm{O}$ & 2.74 & 3.24 & 3.51 & 2.71 & 4.20 & 4.15 & 3.5 & 4.11 & 4.08 & 4.62 & 4.08 & 3.18 \\
\hline $\mathrm{TiO}_{2}$ & 2.09 & 1.86 & 1.5 & 2.24 & 1.01 & 1.53 & 1.17 & 1.07 & 1.16 & 0.51 & 0.68 & 0.73 \\
\hline $\mathrm{P}_{2} \mathrm{O}_{5}$ & 0.59 & 0.59 & 0.7 & 0.35 & 0.30 & 0.46 & 0.20 & 0.41 & 0.23 & 0.16 & 0.22 & 0.17 \\
\hline $\mathrm{MnO}$ & 0.18 & 0.18 & 0.14 & 0.18 & 0.13 & 0.13 & 0.16 & 0.11 & 0.10 & 0.10 & 0.06 & 0.08 \\
\hline LOI & 1.38 & 1.13 & 1.12 & 2.05 & 0.91 & 0.60 & 0.65 & 0.47 & 1.19 & 0.44 & 0.90 & 0.53 \\
\hline $\mathrm{Mg}^{\#}$ & 47 & 46 & 45 & 47 & 50.66 & 51.61 & 59.2 & 44.3 & 50.92 & 43.84 & 49.90 & 50.1 \\
\hline $\mathrm{A} / \mathrm{CNK}$ & 0.685 & 0.719 & 0.784 & 0.732 & 0.98 & 0.89 & 0.84 & 0.91 & 0.99 & 1.00 & 1.01 & 0.93 \\
\hline $\mathrm{Cr}$ & 14.6 & 45.9 & 20 & 20 & 22 & 7.27 & 23.3 & 24.10 & 20 & 13.1 & 7.7 & 20.5 \\
\hline $\mathrm{Ni}$ & 28.9 & 22.9 & 13.5 & 28.1 & 10.0 & 6.47 & 8.56 & 12.5 & 6.8 & 5.23 & 4.21 & 10 \\
\hline Co & 54.2 & 42.5 & 27.1 & 45.4 & 12.1 & 23.5 & 26.5 & 15.0 & 20.3 & 4.48 & 5.06 & 9.64 \\
\hline $\mathrm{Rb}$ & 9.75 & 10.5 & 6.5 & 14.8 & 56.7 & 37.0 & 28.9 & 84.8 & 46.7 & 84.7 & 124 & 186 \\
\hline Cs & 1.1 & 0.98 & 0.6 & 1.15 & 3.96 & 1.31 & 1.15 & 1.40 & 2.6 & 1.11 & 3.36 & 6.57 \\
\hline $\mathrm{Sr}$ & 809 & 1060 & 1585 & 987 & 536 & 710 & 603 & 733 & 677 & 331 & 534 & 208 \\
\hline $\mathrm{Ba}$ & 320 & 255 & 250 & 250 & 1350 & 621 & 405 & 789 & 471 & 1070 & 1240 & 729 \\
\hline $\mathrm{V}$ & 376 & 306 & 253 & 412 & 97.1 & 198 & 218 & 92.7 & 137 & 35.7 & 42.9 & 81.8 \\
\hline $\mathrm{Sc}$ & 29.7 & 24.3 & 12.6 & 24.7 & 15.2 & 19.8 & 22.7 & 8.25 & 6.7 & 6.69 & 3.15 & 11.4 \\
\hline $\mathrm{Nb}$ & 3.93 & 3.71 & 3.4 & 3.8 & 8.35 & 5.95 & 4.27 & 8.98 & 4.9 & 9.56 & 10.6 & 10.6 \\
\hline $\mathrm{Ta}$ & 0.22 & 0.19 & 0.2 & 0.2 & 0.53 & 0.34 & 0.27 & 0.34 & 0.3 & 0.48 & 0.93 & 0.85 \\
\hline $\mathrm{Zr}$ & 62.4 & 46.4 & 48 & 61 & 300 & 389 & 59.5 & 318 & 36 & 499 & 217 & 307 \\
\hline Hf & 2.37 & 1.9 & 1.6 & 1.9 & 5.93 & 7.21 & 2.37 & 7.97 & 1.5 & 10.2 & 5.22 & 7.57 \\
\hline $\mathrm{U}$ & 0.18 & 0.15 & 0.13 & 0.32 & 0.95 & 0.83 & 0.63 & 0.61 & 0.64 & 0.66 & 3.76 & 4.05 \\
\hline Th & 0.41 & 0.27 & 0.28 & 0.47 & 5.81 & 2.08 & 3.20 & 7.97 & 5.19 & 1.82 & 18.1 & 22.2 \\
\hline $\mathrm{La}$ & 14.9 & 16.2 & 17.5 & 12.1 & 24.6 & 20.9 & 17.3 & 47.9 & 19.3 & 21.6 & 40.6 & 34.2 \\
\hline
\end{tabular}


Table 3. Cont.

\begin{tabular}{ccccccccccccc}
\hline Sample & B4117-1 & B4117-2 & Yh59-2 & Yh59-3 & Dh034 & Dh041 & $\mathbf{1 2 4 5 - 1}$ & N-8 & B4396-1 & 4119-1 & YH34 & 4134-1 \\
\hline $\mathrm{Ce}$ & 35.8 & 37.8 & 42 & 30.3 & 52.3 & 46.0 & 36.7 & 76.0 & 39 & 39.7 & 80.7 & 74.3 \\
$\mathrm{Pr}$ & 5.71 & 5.94 & 6.15 & 4.77 & 7 & 6.39 & 4.87 & 9.54 & 4.9 & 5.5 & 7.58 & 9.63 \\
$\mathrm{Nd}$ & 27.6 & 27.9 & 28.2 & 22.8 & 27.6 & 26.9 & 20.2 & 35.3 & 20 & 21.9 & 26.3 & 35.9 \\
$\mathrm{Sm}$ & 6.53 & 6.27 & 5.95 & 5.43 & 5.65 & 5.75 & 4.40 & 6.08 & 4.01 & 4.01 & 4.31 & 7.49 \\
$\mathrm{Eu}$ & 1.93 & 1.94 & 2.21 & 2.03 & 2.33 & 1.71 & 1.26 & 1.03 & 1.52 & 1.07 & 1.13 & 1.08 \\
$\mathrm{Gd}$ & 5.67 & 5.32 & 5.59 & 5.78 & 4.96 & 4.92 & 3.90 & 5.03 & 4.18 & 3.23 & 3.17 & 6.04 \\
$\mathrm{~Tb}$ & 0.94 & 0.86 & 0.76 & 0.81 & 0.74 & 0.77 & 0.63 & 0.72 & 0.57 & 0.51 & 0.44 & 0.94 \\
$\mathrm{Dy}$ & 5.13 & 4.62 & 4.16 & 4.59 & 3.89 & 4.88 & 3.52 & 3.57 & 2.79 & 2.76 & 2.01 & 5.68 \\
$\mathrm{Ho}$ & 0.95 & 0.85 & 0.79 & 0.89 & 0.79 & 0.98 & 0.67 & 0.65 & 0.49 & 0.53 & 0.37 \\
$\mathrm{Er}$ & 2.58 & 2.33 & 2.02 & 2.27 & 2.28 & 2.72 & 1.85 & 1.79 & 1.13 & 1.57 & 1 \\
$\mathrm{Tm}$ & 0.38 & 0.34 & 0.27 & 0.31 & 0.35 & 0.41 & 0.27 & 0.27 & 0.14 & 0.25 & 0.16 \\
$\mathrm{Yb}$ & 2.44 & 2.15 & 1.55 & 1.84 & 2.25 & 2.72 & 1.81 & 1.78 & 0.78 & 1.83 & 1.08 & 3.01 \\
$\mathrm{Lu}$ & 0.37 & 0.32 & 0.24 & 0.28 & 0.34 & 0.41 & 0.28 & 0.28 & 0.12 & 0.31 & 0.16 & 0.45 \\
$\mathrm{Y}$ & 28.6 & 25.3 & 19.7 & 22.1 & 22.5 & 28.3 & 21.3 & 22.6 & 12.4 & 17.5 & 12.6 & 34.7 \\
$\mathrm{KEE}$ & 110.93 & 112.84 & 117.39 & 94.2 & 135.08 & 125.46 & 97.66 & 189.94 & 98.93 & 104.77 & 169.01 & 183.28 \\
$\mathrm{Nb} / \mathrm{Ta}$ & 17.86 & 19.53 & 17.00 & 19.00 & 15.75 & 17.50 & 15.81 & 26.41 & 16.33 & 19.92 & 11.40 & 12.47 \\
$\mathrm{Zr} / \mathrm{Hf}$ & 26.33 & 24.42 & 30.00 & 32.11 & 50.59 & 53.95 & 25.11 & 39.90 & 24.00 & 48.92 & 41.57 & 40.55 \\
$\mathrm{Ba} / \mathrm{Rb}$ & 32.82 & 24.29 & 38.46 & 16.89 & 23.81 & 16.78 & 14.01 & 9.30 & 10.09 & 12.63 & 10.00 & 3.92 \\
$(\mathrm{La} / \mathrm{Yb})_{\mathrm{N}}$ & 4 & 5 & 8 & 4 & 7.37 & 5.18 & 6.44 & 18.14 & 16.68 & 7.96 & 25.34 & 7.69 \\
$\mathrm{SEu}$ & 0.97 & 1.03 & 1.17 & 1.11 & 1.35 & 0.98 & 0.93 & 0.57 & 1.14 & 0.91 & 0.93 & 0.49 \\
\hline
\end{tabular}

Note: The samples of B4117-1, B4117-2, Yh59-2, and Yh59-3 are in this paper; other samples are collected from Guan et al. [35].

Table 4. Sr-Nd isotopic data for the Early Triassic gabbros in the study area.

\begin{tabular}{|c|c|c|c|c|c|c|c|c|c|c|c|c|}
\hline Sample & $\mathbf{t}(\mathrm{Ma})$ & ${ }^{87} \mathrm{Rb} /{ }^{86} \mathrm{Sr}$ & ${ }^{87} \mathrm{Sr} /{ }^{86} \mathrm{Sr}$ & $2 \sigma\left(\times 10^{-6}\right)$ & ${ }^{147} \mathrm{Sm} / 144 \mathrm{Nd}$ & ${ }^{143} \mathrm{Nd} /{ }^{144} \mathrm{Nd}$ & $2 \sigma\left(\times 10^{-6}\right)$ & Isr & $\varepsilon_{N d}(t)$ & $T_{\mathrm{DM} 1}$ & $T_{\mathrm{DM} 2}$ & $f_{\mathrm{Sm} / \mathrm{Nd}}$ \\
\hline B4117 & 251 & 0.0349 & 0.70511 & 3 & 0.1513 & 0.51274 & 4 & 0.70499 & 3.4 & 1005 & 743 & -0.23 \\
\hline B3164-1 & 251 & 1.5093 & 0.70915 & 3 & 0.1265 & 0.512561 & 8 & 0.70376 & 0.7 & 1032 & 963 & -0.36 \\
\hline
\end{tabular}




\section{Discussion}

\subsection{Petrogenesis}

\subsubsection{Petrogenesis of Late Permian Diorites}

The Late Permian diorites are characterized by low contents of $\mathrm{SiO}_{2}$ and high contents of $\mathrm{Al}_{2} \mathrm{O}_{3}$, implying the characteristics of high Al-rocks. The high initial ${ }^{87} \mathrm{Sr} /{ }^{86} \mathrm{Sr}$ ratios show the magma source is of crustal origin [34]. While the low contents of $\mathrm{Cr}$ and $\mathrm{Ni}$ also indicate that the parental magma of quartz diorite is not mantle-derived but represent a crustal source. In addition, the high Th/U ratios and low $\mathrm{Cr}\left(7.27 \times 10^{-6}-24.10 \times 10^{-6}\right)$ and $\mathrm{Ni}\left(6.47 \times 10^{-6}-12.5 \times 10^{-6}\right)$ concentrations of these diorites [34] are inconsistent with melts derived from N-MORB or delaminated lower crust ([34] and reference therein). However, the low $\mathrm{SiO}_{2}$, high $\mathrm{Fe}_{2} \mathrm{O}_{3}, \mathrm{FeO}$, and $\mathrm{TiO}_{2}$ contents imply a mantle source for the magma because they are distinct from the magmas originated from crust derived melts or crustal materials. The zircon $\varepsilon \mathrm{Hf}(\mathrm{t})$ values and $\mathrm{T}_{\mathrm{DM} 2}$ ages of zircons from the diorites range from +0.5 to +9.5 and from 853 to $1669 \mathrm{Ma}$, respectively, suggesting that the primary magma of the diorite was from the mantle or was influenced by crustal material. Taken together with the high ${ }^{87} \mathrm{Sr} /{ }^{86} \mathrm{Sr}$ and negative $\varepsilon \mathrm{Nd}(\mathrm{t})$ isotopic data [34], we suggest that the primary magma for Late Permian diorites should be derived from the mantle and is influenced by crustal material during magma ascent.

\subsubsection{Petrogenesis of the Early Triassic Mafic Rocks}

Geochemically, the mafic rocks have high contents of $\mathrm{Al}_{2} \mathrm{O}_{3}$ and $\mathrm{Na}_{2} \mathrm{O}+\mathrm{K}_{2} \mathrm{O}$ and have the alkali features in the TAS (Figure 6A). While the low $\mathrm{SiO}_{2}$ and high $\mathrm{Cr}, \mathrm{Ni}$, Co, and Sc contents along with high Mg\# values indicate that the mafic magma is not from crustal derived melts [54,55] or crustal materials [56], but is from a mantle source [57]. Furthermore, the ratios of $\mathrm{Nb} / \mathrm{Ta}, \mathrm{Zr} / \mathrm{Hf}$, and $\mathrm{Ba} / \mathrm{Rb}$ are 17.00-19.53, 24.42-32.11, and 16.89-38.46, respectively, similar with the ratios of mantle magmas [56]. However, understanding the effects of crustal contamination on the mafic rocks is important because crustal contamination is almost inevitable during the ascent of mantle-derived melts through continental crust, and modifies the chemical and isotopic compositions during magma evolution [58]. The depletion of $\mathrm{Nb}$ and Ta implies that the parental magma of mafic rocks is related to crustal contamination or magma mixing during the ascent of magmas [59] or reflect magma generation in a subduction-related environment [60]. Due to the existence of xenocrystic zircon ( 700 Ma) in sample N-8 [34], the contamination probably occurred during magma emplacement. Nevertheless, the process of magma mixing or crustal contamination could be ignored and a comprehensive consideration of the geochemical data could answer this question because of the following reasons: (1) consider to the enrichment of $\mathrm{Zr}$ and Hf in crustal materials, minor crustal contamination could result in positive $\mathrm{Zr}-\mathrm{Hf}$ anomalies [61,62]. The mafic rocks in this study have the negative Zr-Hf anomalies (Figure 7B), suggesting that the mafic magmas are affected by little or no crustal material. (2) Lu/Yb ratios of the samples are about 0.15 and are consistent with those of mantle-derived magmas (0.14-015), while the continental crust has relatively high $\mathrm{Lu} / \mathrm{Yb}$ ratios of $0.16-0.18$ [56]. Additionally, the gabbros have low initial ${ }^{87} \mathrm{Sr} /{ }^{86} \mathrm{Sr}(0.70376-0.70499)$ and positive $\varepsilon \mathrm{Nd}(\mathrm{t})(+0.7$ to +3.4$)$, which indicate that the magma of the Early Triassic mafic rocks is from the mantle. Furthermore, the $\varepsilon H f(t)$ values and $T_{D M 2}$ ages of zircons from the gabbros range from +7.6 to +10.7 and from 735 to 1022 Ma respectively, suggesting that the primary magma of gabbros could be derived from partial melting of a lithospheric mantle source. 
Significant crustal contamination did not affect the Early Triassic mafic rocks. In contrast, fractional crystallization is commonly responsible for the petrologic and geochemical variations among the different intrusive rocks in the orogenic zone ([58] and reference therein). The absence of Eu anomalies (Figure 7A) in the REE pattern suggests that no plagioclase fractionation occurred in the mantle magmas. The negative correlations between $\mathrm{MgO}$ and $\mathrm{SiO}_{2}$ and $\mathrm{Al}_{2} \mathrm{O}_{3}$, coupled with the positive correlations between $\mathrm{MgO}$ and $\mathrm{CaO}$, as well as $\mathrm{Cr}$ and $\mathrm{Ni}$ (Figure 8), indicate that ferromagnesian minerals such as olivine and clinopyroxene are major fractionating phases. In addition, the positive correlation between $\mathrm{V}$ and $\mathrm{TiO}_{2}$ imply hornblende fractionation (Figure $8 \mathrm{~F}$ ).

\subsubsection{Petrogenesis of Triassic Granitic Rocks}

Compared to the geochemical features of the Early Triassic gabbros, the Early Triassic granites have high $\mathrm{SiO}_{2}, \mathrm{Al}_{2} \mathrm{O}_{3}$ contents, and $\left(\mathrm{K}_{2} \mathrm{O}+\mathrm{Na}_{2} \mathrm{O}\right)$ contents and high $\mathrm{K}_{2} \mathrm{O} / \mathrm{Na}_{2} \mathrm{O}$ ratios and $\mathrm{Fe}_{2} \mathrm{O}_{3} / \mathrm{FeO}$ ratios showing a shoshonitic affinity. In the $\mathrm{Ta} / \mathrm{Yb}$ vs. $\mathrm{Ce} / \mathrm{Yb}$ and $\mathrm{Ta} / \mathrm{Yb}$ vs. $\mathrm{Ce} / \mathrm{Yb}$ diagrams (Figure 9), the samples are plotted into the calc-alkaline to shoshonitic series. Furthermore, the samples are enriched in LREE, such as $\mathrm{Ba}$ and $\mathrm{Sr}$, and depleted in $\mathrm{Ta}, \mathrm{Nb}$, and Ti (Figure 7B), indicating that the Early Triassic granites are shoshonitic rocks. The shoshonitic rocks with low $\mathrm{SiO}_{2}(<56 \%)$ content origins have been attributed to different main types of petrogenetic scenario [63-67], but the shoshonitic rocks with high $\mathrm{SiO}_{2}(>63 \%)$ are supposed to derive from the partial melting of lower crust materials ([48] and reference therein). In our study, our samples have high $\mathrm{Th}, \mathrm{U}, \mathrm{Zr}$, and Hf contents and rocks mostly have $\mathrm{K}, \mathrm{Zr}$, and $\mathrm{Hf}$ positive anomaly in the spidergrams (Figure $7 \mathrm{~B}$ ), implying the magma is from the crust. Additionally, zircons from the granites in the study area have $\varepsilon \mathrm{Hf}(\mathrm{t})$ values of -4.8 to +9.4 and $\mathrm{T}_{\mathrm{DM} 2}$ ages of 852 to $2136 \mathrm{Ma}$, indicating that the primary magma of the Early Triassic granites could be mainly derived from partial melting of the crust, with minor contribution of the crustal material of an ancient crust (Figure 5, [33]). This interpretation is further supported by initial ${ }^{87} \mathrm{Sr} /{ }^{86} \mathrm{Sr}(0.70429-0.70581)$ and $\varepsilon \mathrm{Nd}(\mathrm{t})(-2.5$ to +1.2$)$ of the granites [34] and the studies of the coeval granites along the Changchun-Yanji suture [33].
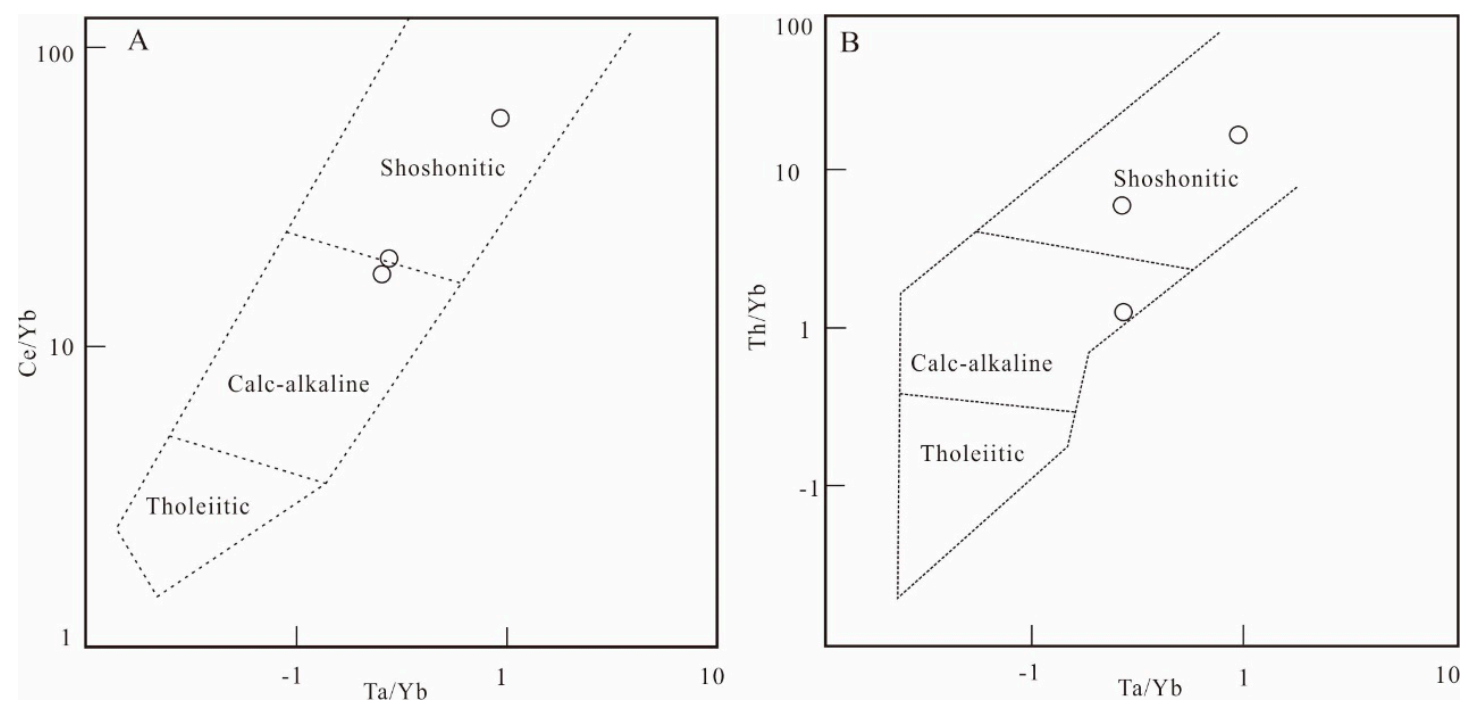

Figure 9. Diagrams showing the shoshonitic affinity of granitic rocks. (A) The diagram of $\mathrm{Ta} / \mathrm{Yb}$ vs. $\mathrm{Ce} / \mathrm{Yb}$ for granitic rocks; (B) The diagram of $\mathrm{Ta} / \mathrm{Yb}$ vs. $\mathrm{Th} / \mathrm{Yb}$ for granitic rocks. 


\subsection{Tectonic Setting of the Early Triassic Bimodal Igneous Rocks}

Geochemically, the Early Triassic granites have an affinity to shoshonitic rocks. The different models for shoshonitic petrogenesis imply these rocks could be formed in various tectonic settings but are mainly formed in an extensional setting [68]. Importantly, the granites and coeval gabbros of this study represent a bimodal igneous rock association, indicating that these rocks formed in an extensional setting in the Early Triassic. Furthermore, the gabbros have high $\mathrm{Al}_{2} \mathrm{O}_{3}$ concentrations, similar with those of high-Al basalts, which are generally considered to be related to arcs or mid-ocean ridges [69-71]. Additionally, granites and hornblende gabbros in the study area also show typical arc magmatic signatures, such as enrichment in LILE, depletion in HFSE, and fractionated REE patterns. In the $\mathrm{Th} / \mathrm{Yb}$ versus $\mathrm{Nb} / \mathrm{Yb}$ and $\mathrm{La} / \mathrm{Yb}$ versus $\mathrm{Th} / \mathrm{Yb}$ diagrams (Figure 10), all the samples in the study area are in the field of continental arcs and alkaline arcs. Combined with the presence of the coeval bimodal igneous rock association in central-eastern Jilin Province [31,33], we propose that the Early Triassic rocks in the Yanbian area formed in an extensional setting related to the breakoff of the previously subducted slab [33].
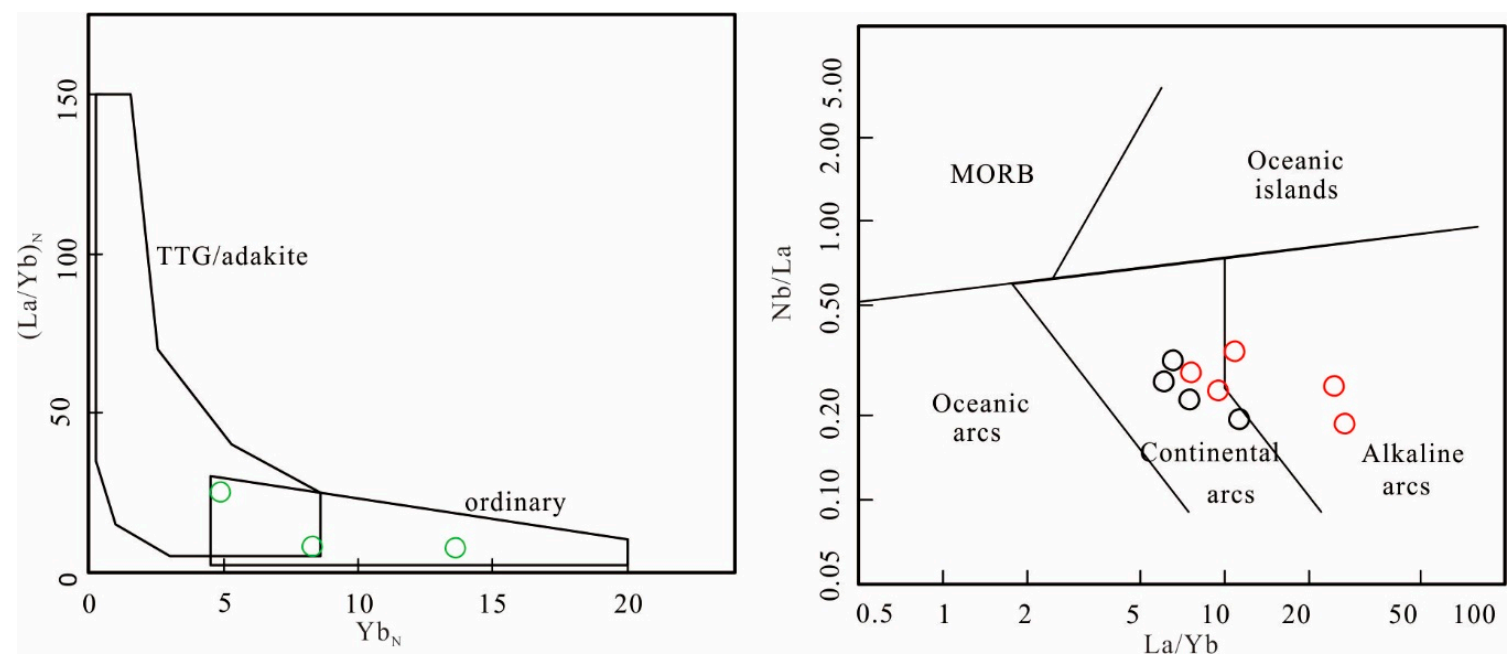

Figure 10. Diagrams of $\mathrm{Yb}_{\mathrm{N}}$ versus $(\mathrm{La} / \mathrm{Yb})_{\mathrm{N}}$ for Early Triassic granitic rocks and $\mathrm{La} / \mathrm{Yb}$ versus $\mathrm{Nb} / \mathrm{La}$ for the Late Permian diorites and the Early Triassic gabbros of this study.

\subsection{Late Carboniferous to Triassic Magmatic Events in the Yanbian Area}

It has been suggested that the final closure of the Paleo-Asian Ocean occurred in Yanbian area $[4,5,12,16,18,22,24,30,32,33,58,72]$. However, knowledge of the origin of magmas along the terminal zone is important in understanding the tectonic evolutionary processes during subduction, collision, and extension [73]. Therefore, the Late Paleozoic-Early Mesozoic magmatic rocks in the Yanbian area could throw new light on the final closure of Paleo-Asian Ocean. According to a compilation of the existing Late Carboniferous to Triassic magmatic rocks data $[5,12,16,22,24,30,32,33,72]$, five main tectono-magmatic episodes could be identified in Yanbian area, easternmost segment of CAOB: (1) Late Carboniferous-Early Permian (305-270 Ma), (2) Middle-Late Permian (270-252 Ma), (3) Early Triassic (251 Ma-245 Ma), (4) Middle Triassic (245-235 Ma), and (5) Late Triassic (230-210 Ma) (Figure 11). 


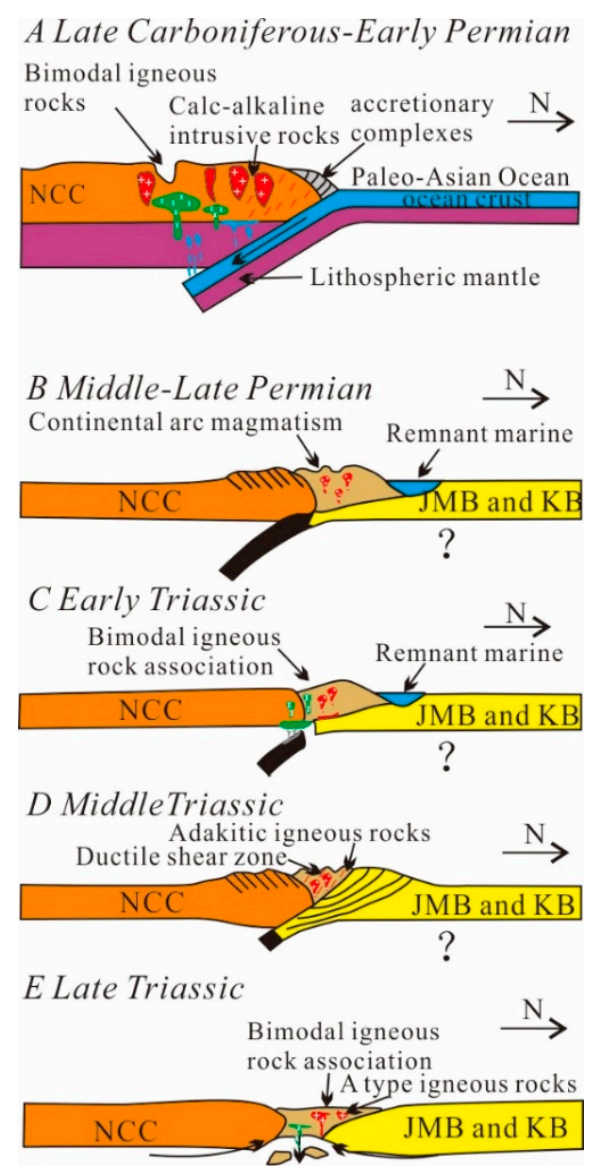

Figure 11. Late Carboniferous-Late Triassic tectonic evolution in the Yanbian area, not the Latest Permian-Early Jurassic tectonic evolution in the Yanbian area. NCC-North China Craton, JMB-Jiamusi Block, and KB-Khanka Block.

\subsubsection{The Late Carboniferous-Early Permian Magmatic Event in Yanbian Area}

The Late Carboniferous-Early Permian igneous rocks in the Yanbian area, including tonalites, gabbros and basalt-andesites, are mainly outcropping in the Hunchun and Bailiping areas [16,22]. Geochemically, the tonalites belong to the calc-alkaline series with I-type igneous features and have an affinity to adakitic magmas, indicating that the magma could have been derived from the partial melting of subducting oceanic slab material in an active continental margin setting [16]. Meanwhile, the gabbros and basalt-andesites belong to the low-K tholeiitic series and have similar geochemical features to high-aluminum basalts that formed in an island arc setting [22,31]. Furthermore, the coeval volcanic rocks, interpreted as the product of subduction, are also reported in the Huadian area, central Jilin Province [72]. Taken together, the petrogenesis and tectonic setting of Late Carboniferous-Early Permian rocks reveal that the subduction of the Paleo-Asian Ocean in the Yanbian area occurred in the Late Carboniferous-Early Permian (Figure 11A).

\subsubsection{The Middle-Late Permian Magmatic Event in the Yanbian Area}

Importantly, along with the Middle-Late Permian magmatic rocks in the Yanbian area, coeval calc-alkaline to high-K calc-alkaline I-type magmatic rocks were reported from the western segments of the Changchun-Yanji belt, such as from the Huadian region, and the southern Changchun, Bailiping and Helong areas $[12,16,22,24,30,31,33,34,58,72]$, and form an E-W-trending magmatic s belt of continental arc magmatic rocks. The Middle-Late Permian magmatic rocks in the Yanbian area, including basalts, monzogranites, diorites, gabbros, and granodiorites, are enriched in LILEs, depleted in HFSEs and have low initial ${ }^{87} \mathrm{Sr} /{ }^{86} \mathrm{Sr}$ ratios and positive $\varepsilon_{\mathrm{Nd}}(\mathrm{t})$ values, suggesting their magma source regions have 
undergone metasomatism by subduction-related fluids [12,58]. Furthermore, the Late Permian high-Mg andesites occur along the Changchun-Yanji belt in the eastern CAOB segment and are interpreted as the products of partial melting of enriched mantle induced by dehydration of a subducted slab [74]. However, the Middle-Late Permian intrusive rocks in the Yanbian area formed in a continental arc setting (Figure 11B; [16,34]).

\subsubsection{The Early Triassic Magmatic Event in the Yanbian Area}

The Early Triassic intrusive rocks form a similar bimodal igneous association to the Late Permian bimodal igneous rocks in the central Jilin Province $[31,33,75]$, indicating that they formed in an extensional setting. Furthermore, the geochemical features imply a shoshonitic affinity of the Early Triassic rocks; also, suggesting the existence of an extensional setting. Combined with the Late Permian continental arc setting, the Early Triassic bimodal igneous rocks are likely to have formed in an extensional setting due to the break-off of the previously subducted slab in the Yanbian area (Figure 11C).

\subsubsection{The Middle Triassic Magmatic Events in Yanbian Area}

The Middle Triassic intrusive rocks are composed of quartz monzonite, monzogranite, and syenogranite, characterized by high $\mathrm{Sr}$, low $\mathrm{Y}$, and $\mathrm{Yb}$ contents classifying these as adakitic rocks $[16,20,31,33]$. This implies that these rocks formed in a compressional tectonic setting (Figure 11D). Additionally, a few Middle Triassic metamorphic zircons are distinguished, indicating the Middle Triassic metamorphic ages were recorded from the Huangyingtun Formation (233 Ma; [28]), Kedao Group (241 Ma and $231 \mathrm{Ma}$; [15,29]), and Jiefangcun (234 Ma; [29]) and Sidonggou Formations (233 Ma; [29]) in the Yanbian area. In summary, the Middle Triassic adakitic rocks formed in a compressional tectonic setting, indicating the final closure of the Paleo-Asian Ocean.

\subsubsection{The Late Triassic Magmatic Event in Yanbian Area}

Based on the E-W trending spatial distribution of Late Triassic igneous rocks along the final suture, the Late Triassic magmatic events are linked to the tectonic evolution of the Paleo-Asian Ocean, rather than the subduction of the Paleo-Pacific Plate [32]. The Late Triassic igneous rocks in the Yanbian area include mafic-ultramafic intrusions, I-A-type granitoids and A-type rhyolites and are interpreted to have formed in an extensional environment [16,76,77]. Additionally, the extensional events are also recorded by the Late Triassic Dajianggang Formation (molasse) [28] and structural analysis in the Hulan group [78]. Furthermore, metamorphic ages were also recorded in the Hulan (Ar-Ar, biotite, $\sim 220 \mathrm{Ma}$; [78]) and Kedao Groups (metamorphic zircon, 210 Ma; [15]). Thereby, we suggest that the Late Triassic rocks in Yanbian area formed in an extensional setting related to the tectonic evolution of the Paleo-Asian Ocean (Figure 11E).

\subsection{Tectonic Implications}

\subsubsection{Eastward Extent of the Solonker-Xar Moron-Changchun Suture}

The study area is located in the Yanbian area of the easternmost CAOB. However, it is well known that the $\mathrm{CAOB}$ underwent ocean basin closure, terrane amalgamation, crustal thickening, accretion, and lithospheric delamination during Permian-Triassic times [5,12,15,16,18,22,24,29,33]. Additionally, it is widely accepted that the Paleo-Asian Ocean finally closed during the Late Permian-Middle Triassic [5,12,15,16,18,22,24,29,33]. Thus, due to lack of ophiolite outcrops in the central-eastern Jilin Province (the eastern CAOB), fierce debate continues over whether the Yanbian area is the eastward extension of the Solonker suture belt or not $[5,18,19]$. Some scholars have suggested that the Yanbian area is a suture zone related to the subduction of the Paleo-Pacific Ocean instead of the Paleo-Asian Ocean during the Permo-Triassic period [19]. On the contrary, the other popular 
proposal suggests that the Yanbian area is the site of the closure of the Paleo-Asian Ocean, and therefore constitutes the eastern part of the CAOB $[5,12,15,16,18,22,24,29,33]$.

Based on increasing evidences during the past decades $[5,12,15,16,18,22,24,28,29,33]$, we suggest that the Changchun-Yanji belt is the easternmost part to the Solonker-Xar Moron-Changchun Suture zone, which records the final closure of the Paleo-Asian Ocean. The evidences include as follows: (1) Paleozoic-Early Mesozoic magmatic events occurred in the Changchun and Yanbian areas along the Solonker-Xar Moron-Changchun-Yanji [5,12,16,18,22,24,33]. These magmatisms represent independent regional tectonic events and are similar with the products of the five Late Paleozoic evolution stages of the western Solonker-Xar Moron-Changchun-Yanji Suture zone proposed by Jian et al., 2010 [14]. Furthermore, due to the detachment and sinking of subducted slabs of the Paleo-Asian Oceanic plate after closure, the Changchun and Yanbian areas (eastern Solonker-Xar Moron-Changchun-Yanji Suture zone) is within an extensional setting during 255-242 Ma. This view is also supported by the existence of the bimodal magmatism and molasse in the study and adjacent areas $[15,28,29]$. Additionally, the Early-Middle Triassic adakitic rocks outcrop along the Changchun-Yanji belt with the coeval metamorphic events recorded in the Hulan and Kedao Groups, and Huangyingtun and Sidaogou Formations [16,31,33]. (2) The Permian strata in the northern part of the Yanbian area are composed of Hesheng, Dasuangou, and Kaishantun Formations and contain mainly detritus from NCC sources while the source of Wudaogou Group in the northern part of the Yanbian area is mainly from the Jiamusi block ([29] and references therein). Therefore, the distribution and composition of Permian formations in Yanbian area indicate that the Yanbian area is the suture belt between the northern NCC and the Jiamusi block and Khanka block. (3) The Kaishantun and Hesheng flora are mainly Cathaysia flora, while the Jiefangcun flora is a mixture of the Cathaysian and the Angaran flora elements ([29] and reference therein). Anyway, the coeval mixture of cool-and warm-water faunas are also reported in central Jilin Province and Inner Mongolia and coexists along the Solonker-Xar Moron-Changchun-Yanji Suture zone in E-W direction ([29] and references therein). Considering the magmatic, sedimentary, metamorphic, and sedimentary evidences, we suggest that the Late Permian-Early Triassic magmatism in the study area is linked with the final subduction of Paleo-Asian Ocean.

5.4.2. The Final Scissor-Like Closure Model of the Paleo-Asian Ocean in Easternmost Central Asian Ocean Belt

Many studies have suggested that the final closure of the Paleo-Asian Ocean occurred from west to east along the Solonker-Xar Moron-Changchun-Yanji suture zone in a scissor-like closure model [4,8-13]. However, the precise timing of final closure is debated [15,16,18,28,30,31,33]. According to a compilation of existing data, three main tectonic episodes could be identified that are linked to the closure of the Paleo-Asian Ocean in the Yanbian area, the easternmost of Central Asian Ocean Belt. (1) The Late Carboniferous to Early Triassic development of subduction-collision-extension systems are related to the subduction of Paleo-Asian Ocean. (2) The Middle Triassic tectonic development relates to compression and thickening of the continental crust. (3) A Late Triassic post-collision extensional stage followed. However, the Early Triassic bimodal igneous rocks are likely to record the final subduction of the Paleo-Asian Ocean, while the Middle Triassic adakitic rocks record collision between the North China Craton and combined Jiamusi and Khanka blocks. Furthermore, a similar rocks association occurs in the central Jilin Province, which relates to the Yanbian area $[31,33,75]$.

Considering the emplacement ages of bimodal and adakitic rocks in the central Jilin Province and Yanbian area, we suggest that the final closure of Paleo-Asian Ocean in central Jilin Province is during Early Triassic while it occurred in the Yanbian area during Middle Triassic times (Wang et al., 2015). Furthermore, the Angaran and Cathaysian floras mixed during the Late Permian-Middle Triassic in the Yanbian area and delineate the final closure of Paleo-Asian Ocean in the eastern segment of CAOB [29]. 
In brief, based on the magmatic, metamorphic and sedimentary events along Changchun-Yanbian belt, we suggest that the final closure of Paleo-Asian Ocean occurred in a scissor-like manner in the Yanbian area, the easternmost segment of CAOB, during the Middle Triassic times (Figure 12).

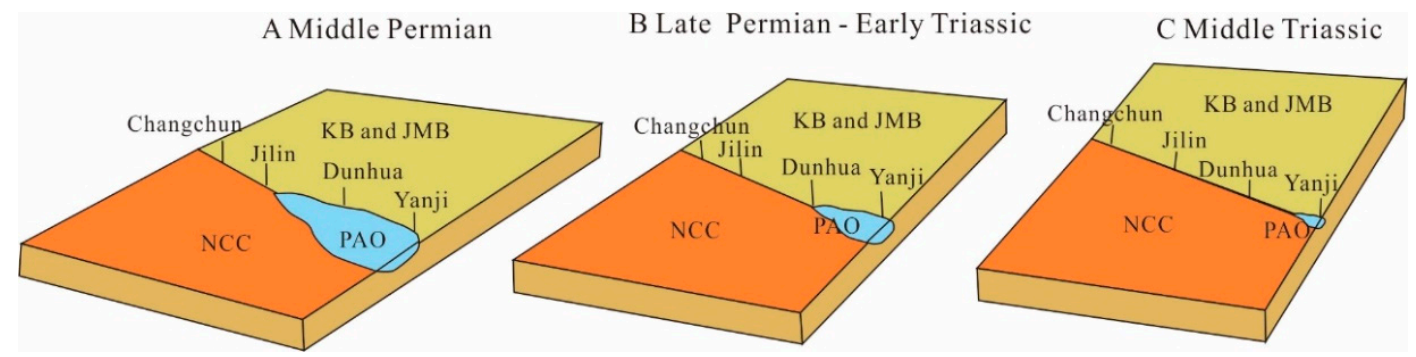

Figure 12. Simplified model showing the Middle Permian-Middle Triassic tectonic evolution of the northern margin of the North China Craton (NCC) and the combined Khanka (KB) and Jiamusi Blocks (JMB). PAO_Paleo-Asian Ocean.

\section{Conclusions}

1. LA-ICP-MS zircon U-Pb dating indicates that mafic and granitic intrusions in the Helong area of NE China formed in Late Permian ( 257 Ma) and Early Triassic ( 251 Ma) times.

2. The Late Permian diorites show the petrologic and geochemical characteristics of arc type igneous rocks enriched in LILE and depleted in HFSE. The geochemical and isotopic features suggest that the primary magma for Late Permian quartz diorite should be derived from partial melting of a juvenile lower continental crust.

3. The Early Triassic intrusions including granites and gabbros represent a bimodal igneous rock association. The granites have an affinity to the shoshonitic rocks with enrichment of LILE sand LREEs and depletion of TNT ( $\mathrm{Ta}, \mathrm{Nb}$, and $\mathrm{Ti}$ ). The $\mathrm{Sr}-\mathrm{Nd}$ isotopic and zircon Hf isotopic data show that the primary magma of gabbros could be derived from partial melting of a juvenile lithospheric depleted mantle source whereas the primary magma of the Early Triassic granites could be mainly derived from partial melting of juvenile lower crust, with minor contributions of the crustal material of the NCC.

4. The Early Triassic intrusions formed in an extensional setting due to the breakoff of the previously subducted slab.

Author Contributions: Conceptualization: Z.-H.L.; methodology: C.Z. and F.-H.C.; validation: F.N. and Z.-H.L.; formal analysis and data curation: C.Z. and Q.-B.G.; project administration: C.Z.; writing-original draft: C.Z.; and field work: C.Z., Z.-H.L., and Q.-B.G. All authors have read and agreed to the published version of the manuscript.

Funding: This work was financially co-supported by the National Natural Science Foundation of China (Grant no. 41802238, 41872203, 41902207), Natural Science Foundation of Shandong Province (ZR2019PD010), National Key R\&D Plan (Grant No. 2017YFC0601300-01), Taishan Scholars (ts20190918), and Opening Foundation of Key Laboratory of Mineral Resources Evaluation in Northeast Asia, Ministry of Land and Resources (DBY-KF-18-11).

Acknowledgments: We acknowledge detailed comments of anonymous journal reviewers.

Conflicts of Interest: The authors declare no conflict of interest.

\section{References}

1. Sengör, A.M.C.; Natal'In, B.A.; Burtman, V.S. Evolution of the Altaid Tectonic Collage and Palaeozoic Crustal. Growth in Eurasia. Nature 1993, 364, 299-307. [CrossRef]

2. Jahn, B.M.; Griffin, W.L.; Windley, B. Continental growth in the Phanerozoic: Evidence from Central Asia. Tectonophysics 2000, 328, vii-x. [CrossRef]

3. Xiao, W.J.; Windley, B.F.; Hao, J.; Zhai, M.G. Accretion leading to collision and the Permian Solonker suture, Inner Mongolia, China: Termination of the central Asian orogenic belt. Tectonics 2003, 22, 1-20. [CrossRef] 
4. Liu, Y.J.; Li, W.M.; Feng, Z.Q.; Wen, Q.B.; Neubauer, F.; Liang, C.Y. A Review of the Paleozoic Tectonics in the Eastern Part of Central Asian Orogenic Belt. Gondwana Res. 2017, 43, 123-148. [CrossRef]

5. Wu, F.Y.; Sun, D.Y.; Ge, W.C.; Zhang, Y.B.; Grant, M.L.; Wilde, S.A.; Jahn, M. Geochronology of the Phanerozoic Granitoids in Northeastern China. J. Asian Earth Sci. 2011, 41, 1-30. [CrossRef]

6. Zhou, J.B.; Han, J.; Wilde, S.A.; Guo, X.D.; Zeng, W.S.; Cao, J.L. A Primary Study of the Jilin-Heilongjiang High-pressure Metamorphic Belt: Evidence and Tectonic Implications. Acta Petrol. Sin. 2013, 29, 386-398. (In Chinese with English abstract).

7. Zhang, C.; Liu, Y.J.; Zhang, Z.L.; Cui, F.H.; Zhang, C.; Guan, Q.B.; Li, Y. Deformation and Geochronological Characteristics of Gudonghe Ductile Shear Zone in Yanbian Area. Earth Sci. 2019, 46, 3253-3264. (In Chinese with English abstract).

8. Miao, L.C.; Fan, W.M.; Liu, D.Y.; Zhang, F.Q.; Shi, Y.R.; Guo, F. Geochronology and geochemistry of the Hegenshan ophiolitic complex: Implications for late-stage tectonic evolution of the Inner Mongolia-Daxinganling Orogenic Belt, China. J. Asian Earth Sci. 2008, 32, 348-370. [CrossRef]

9. Xu, B.; Zhao, P.; Bao, Q.Z.; Zhou, Y.H.; Wang, Y.Y.; Luo, Z.W. Preliminary study on the pre-Mesozoic tectonic unit division of the Xing-Meng Orogenic Belt (XMOB). Acta Petrol. Sin. 2014, 30, 1841-1857. (In Chinese with English abstract).

10. Xiao, W.J.; Windley, B.F.; Sun, S.; Li, J.; Huang, B.C.; Han, C.M.; Yuan, C.; Sun, M.; Chen, H.L. A tale of amalgamation of three Permo-Triassic collage systems in Central Asia: Oroclines, sutures, and terminal accretion. Annu. Rev. Earth Planet. Sci. 2015, 43, 477-507. [CrossRef]

11. Wilde, S.A.; Zhou, J.B. The late Paleozoic to Mesozoic evolution of the eastern margin of the Central Asian Orogenic Belt in China. J. Asian Earth Sci. 2015, 113, 909-921. [CrossRef]

12. Ma, X.H.; Chen, C.J.; Zhao, J.X.; Qiao, S.L.; Zhou, Z.H. Late Permian intermediate and felsic intrusions in the eastern Central Asian Orogenic Belt: Final-stage magmatic record of Paleo-Asian Oceanic subduction? Lithos 2019, 326, 265-278. [CrossRef]

13. Feng, Z.Q.; Liu, Y.J.; Li, L.; Jin, W.; Jiang, L.W.; Li, W.M.; Zhao, Y.L. Geochemical and geochronological constraints on the tectonic setting of the Xinlin ophiolite, northern Great Xing'an Range, NE China. Lithos 2019, 326, 213-229. [CrossRef]

14. Jian, P.; Liu, D.Y.; Kröner, A.; Windley, B.F.; Shi, Y.R.; Zhang, W.; Zhang, F.Q.; Miao, L.C.; Zhang, L.Q.; Tomurhuu, D. Evolution of a Permian intraoceanic arc-trench system in the Solonker suture zone, Central Asian Orogenic Belt, China and Mongolia. Lithos 2010, 118, 169-190. [CrossRef]

15. Du, Q.X.; Han, Z.Z.; Shen, X.L.; Han, C.; Song, Z.G.; Gao, L.H.; Han, M.; Zhong, W.J. Geochronology and Geochemistry of Permo-Triassic Sandstones in Eastern Jilin Province (NE China): Implications for Final Closure of the Paleo-Asian Ocean. Geosci. Front. 2019, 10, 683-709. [CrossRef]

16. Tang, J.; Li, A.P.; Xu, W.L. Geochronology and geochemistry of late Carboniferous-Middle Jurassic magmatism in the Helong area, NE China: Implications for the tectonic transition from the Paleo-Asian oceanic to circum-Pacific regime. Geol. J. 2020, 55, 1808-1825. [CrossRef]

17. Xu, B.; Wang, X.C.; Wang, T.; Jahn, B.M.; Kroner, A. Preface. Lithos 2016, 261, 1-4. [CrossRef]

18. Sun, Y.W.; Li, M.S.; Ge, W.C.; Zhang, Y.L.; Zhang, D.J. Eastward termination of the Solonker-Xar Moron River Suture determined by detrital zircon $\mathrm{U}-\mathrm{Pb}$ isotopic dating and Permian floristics. J. Asian Earth Sci. 2013, 75, 243-250. [CrossRef]

19. Tang, K.D.; Shao, J.A.; Li, J.C.; Kang, Z. Nature of the Yanbian Suture Zone and Structure of Northeast Asia. Geol. Bull. China 2004, 23, 885-891. (In Chinese with English abstract).

20. Song, Z.G.; Han, Z.Z.; Gao, L.H.; Gao, L.H.; Geng, H.Y.; Li, X.P.; Meng, F.X.; Han, M.; Zhong, W.J.; Li, J.J.; et al. Permo-Triassic evolution of the southern margin of the Central Asian Orogenic Belt revisited: Insights from Late Permian igneous suite in the Daheishan Horst, NE China. Gondwana Res. 2018, 56, 23-50. [CrossRef]

21. Jia, D.C.; Hu, R.Z.; Lu, Y.; Qiu, X.L. Collision belt between the Khanka block and the North China block in the Yanbian Region, Northeast China. J. Asian Earth Sci. 2004, 23, 211-219.

22. Cao, H.H.; Xu, W.L.; Pei, F.P.; Zhang, X.Z. Permian tectonic evolution in southwestern Khanka Massif: Evidence from zircon $\mathrm{U}-\mathrm{Pb}$ chronology, $\mathrm{Hf}$ isotope and geochemistry of gabbro and diorite. Acta Geol. Sin. 2011, 85, 1390-1402.

23. Ren, Y.S.; Chen, C.; Zou, X.T.; Zhao, H.L.; Hao, Y.J.; Hou, H.N.; Hu, Z.C.; Jiang, G.H. The age, geological setting, and types of gold deposits in the Yanbian and adjacent areas, NE China. Ore Geol. Rev. 2016, 73, 284-297. [CrossRef] 
24. Ma, X.H.; Zhu, W.P.; Zhou, Z.H.; Qiao, S.L. Transformation from Paleo-Asian Ocean Closure to Paleo-Pacificsubduction: New Constraints from Granitoids in the Eastern Jilin-Heilongjiang Belt, NE China. J. Asian Earth Sci. 2017, 144, 261-286. [CrossRef]

25. Guan, Q.B.; Liu, Z.H.; Liu, Y.J.; Li, S.Z.; Wang, S.J.; Chen, Z.X.; Zhang, C. A Tectonic Transition from Closure of the Paleo-Asian Ocean to Subduction of the Paleo-Pacific Plate: Insights from Early Mesozoic Igneous Rocks in Eastern Jilin Province, NE China. Gondwana Res. 2020, in press. [CrossRef]

26. Zhang, Y.; Sun, J.G.; Xing, S.W.; Zhao, K.Q.; Ma, Y.B. Geochronology and metallogenesis of porphyry Mo deposits in east-central Jilin province, China: Constraints from molybdenite Re-Os isotope systematics. Ore Geol. Rev. 2015, 71, 363-372. [CrossRef]

27. Wu, F.Y.; Zhao, G.C.; Sun, D.Y.; Wilde, S.A.; Yang, J.H. The Hulan Group: Its Role in the Evolution of the Central Asian Orogenic Belt of Ne China. J. Asian Earth Sci. 2007, 30, 542-556. [CrossRef]

28. Zhou, Z.B.; Pei, F.P.; Wang, Z.W.; Cao, H.H.; Xu, W.L.; Wang, Z.J.; Zhang, Y. Using detrital zircons from late Permian to Triassic sedimentary rocks in the south-eastern Central Asian Orogenic Belt (NE China) to constrain the timing of the final closure of the Paleo-Asian Ocean. J. Asian Earth Sci. 2017, 144, 82-109. [CrossRef]

29. Shen, X.L.; Du, Q.X.; Han, Z.Z.; Song, Z.G.; Han, C.; Zhong, W.J.; Ren, X. Constraints of zircon U-Pb-Hf isotopes from Late Permian-Middle Triassic flora-bearing strata in the Yanbian area (NE China) on a scissor-like closure model of the Paleo-Asian Ocean. J. Asian Earth Sci. 2019, 183, 103964. [CrossRef]

30. Zhang, Y.B.; Wu, F.Y.; Wilde, S.A.; Zhai, M.G.; Lu, X.P.; Sun, D.Y. Zircon U-Pb ages and tectonic implications of 'Early Paleozoic' granitoids at Yanbian, Jilin Province, Northeast China. Isl. Arc 2004, 13, 484-505. [CrossRef]

31. Cao, H.H.; Xu, W.L.; Pei, F.P.; Wang, Z.W.; Wang, F.; Wang, Z.J. Zircon U-Pb geochronology and petrogenesis of the Late PaleozoicEarly Mesozoic intrusive rocks in the eastern segment of the northern margin of the North China Block. Lithos 2013, 170-171, 191-207. [CrossRef]

32. Yang, D.G.; Sun, D.Y.; Gou, J.; Hou, X.G. U-Pb ages of zircons from Mesozoic intrusive rocks in the Yanbian area, Jilin Province, NE China: Transition of the Paleo-Asian oceanic regime to the circum-Pacific tectonic regime. J. Asian Earth Sci. 2017, 143, 171-190. [CrossRef]

33. Wang, Z.J.; Xu, W.L.; Pei, F.P.; Wang, Z.W.; Li, Y.; Cao, H.H. Geochronology and geochemistry of middle Permian-Middle Triassic intrusive rocks from central-eastern Jilin Province, NE China: Constraints on the tectonic evolution of the eastern segment of the Paleo-Asian Ocean. Lithos 2015, 238, 13-25. [CrossRef]

34. Guan, Q.B.; Li, S.C.; Zhang, C.; Shi, Y.; Li, P.C. Zircon U-Pb Dating, Geochemistry and Geological Significance of the I-type Granites in Helong Area, the Eastern Section of the Southern Margin of Xing-Meng Orogenic Belt. Acta Petrol. Sin. 2016, 32, 2690-2706. (In Chinese with English abstract).

35. Yang, H.; Ge, W.C.; Dong, Y.; Bi, J.H.; Ji, Z.; He, Y.; Jing, Y.; Xu, W.L. Permian subduction of the Paleo-Pacific (Panthalassic) oceanic lithosphere beneath the Jiamusi Block: Geochronological and geochemical evidence from the Luobei mafic intrusions in Northeast China. Lithos 2019, 332, 207-225. [CrossRef]

36. JBGMR (Jilin Bureau of Geology and Mineral Resources). Regional Geology of Jilin Province; Geological Publishing House: Beijing, China, 1988; pp. 1-698. (In Chinese with English abstract).

37. Zhang, C. The Mesozoic Tectonic Evolution of Yanbian Area in the Eastern Segment of Northern Margin of the North China Block; Jilin University: Changchun, China, 2014; pp. 1-150. (In Chinese with English abstract).

38. Zhang, C.; Guo, W.; Xu, Z.Y.; Liu, Z.H.; Liu, Y.J.; Lei, C.C. Study on geochronology, petrogenesis and tectonic implications of monzogranite from the Yanbian area, eastern Jilin Province. Acta Petrol. Sin. 2014, 30, 512-526. (In Chinese with English abstract).

39. Li, H.K.; Geng, J.Z.; Hao, S.; Zhang, Y.Q.; Li, H.M. Study on the using LA-MC-ICPMS to date the U-Pb isotopic age of zircons. Bull. Miner. Petrol. Geochem. 2009, 77, 600-601. (In Chinese with English abstract).

40. Andersen, T. Correction of common lead in $\mathrm{U}-\mathrm{Pb}$ analyses that do not report ${ }^{204} \mathrm{~Pb}$. Chem. Geol. 2002, 192, 59-79. [CrossRef]

41. Geng, J.Z.; Li, H.K.; Zhang, J.; Zhou, H.Y.; Li, H.M. Zircon Hf isotope analysis by means of LA-MC-ICP-MS. Geol. Bull. China 2011, 30, 1508-1513.

42. Li, X.H. Geochemistry of the Longsheng Ophiolite from the southern margin of Yangtze Craton, SE China. Geochem. J. 1997, 31, 323-338. [CrossRef]

43. Jia, L.Q.; Mo, X.X.; Dong, G.W.; Xu, W.Y.; Wang, L.; Guo, X.D.; Wang, Z.H.; Wei, S.G. Genesis of lamprophyres from Machangqing, western Yunnan: Constraints from geochemistry, geochronology and Sr-Nd-Pb-Hf isotopes. Acta Petrol. Sin. 2013, 29, 1247-1260. (In Chinese with English abstract). 
44. Shi, Y.; Liu, Z.H.; Xu, Z.Y.; Wang, X.A.; Zhang, C.; Liu, W.Z.; Chen, X. Isotopic chronology and geochemistry of the Hercynian Yongxin granitoid in Longjing, Jilin Province. Geol. Resour. 2013, 22, 6-13. (In Chinese with English abstract).

45. Yang, J.H.; Wu, F.Y.; Shao, J.A.; Wilde, S.A.; Xie, L.W.; Liu, X.M. Constraints on the timing of uplift of the Yanshan Fold and Thrust Belt, North China. Earth Planet. Sci. Lett. 2006, 246, 336-352. [CrossRef]

46. Irvine, T.H.; Baragar, W.R.A. A guide to the chemical classification of the common volcanic rocks. Can. J. Earth Sci. 1971, 8, 523-548. [CrossRef]

47. Peccerillo, A.; Taylor, A.R. Geochemistry of Eocene calc-alkaline volcanic rocks from the Kastamonu area, Northern Turkey. Contrib. Mineral. Petrol. 1976, 58, 63-81. [CrossRef]

48. Jia, X.H.; Wang, X.D.; Yang, W.Q.; Niu, Z.J. An Overview of Studies on shoshonitic rocks. Geol. Rev. 2017, 63, 1587-1600. (In Chinese with English abstract).

49. Müller, D.; Groves, D.I. Direct and indirect associations between potassic igneous rocks shoshonites and gold-copper deposits. Ore Geol. Rev. 1993, 8, 383-406. [CrossRef]

50. Boynton, W.V. Geochemistry of the Rare Earth Elements Meteorite Studies. In Rare Earth Element Geochemistry; Henderson, P., Ed.; Elsevier Science Publishers: Amsterdam, The Netherlands, 1984; pp. 63-114.

51. Sun, S.S.; McDonough, W.F. Chemical and Isotopic Systematics of Oceanic Basalts: Implications for Mantle Composition and Processes. In Magmatism in Ocean Basins; Saunders, A.D., Norry, M.J., Eds.; Geological Society Special Publications: London UK, 1989; Volume 42, pp. 313-345.

52. Jahn, B.M.; Wu, F.Y.; Chen, B. Massive granitoid generation in Central Asia: Nd isotope evidence and implication for continental growth in the Phanerozoic. Episodes 2000, 23, 82-92. [CrossRef]

53. Wu, F.Y.; Jahn, B.M.; Wilde, S.A.; Sun, D.Y. Phanerozoic continental crustal growth: U-Pb and Sr-Nd isotopic evidence from the granites in northeastern China. Tectonophysics 2000, 328, 89-113. [CrossRef]

54. Patiño Douce, A.E. Experimental generation of hybrid silicic melts by reaction of high-Al basalt with metamorphic rocks. J. Geophys. Res. Atmos. 1995, 1001, 15623-15640. [CrossRef]

55. Patiño Douce, A.E. Generation of metaluminous A-type granites by low-pressure melting of calc-alkaline granitoids. Geology 1997, 25, 743-746. [CrossRef]

56. Rudnick, R.L.; Gao, S. The Composition of the Continental Crust. In the Crust; Rudnick, R.L., Ed.; Elsevier-Pergamon: Oxford, UK, 2003; pp. 1-64.

57. Frey, F.A.; Prinz, M. Ultramafic inclusions from San Carlos, Arizona: Petrologic and geochemical data bearing on their petrogenesis. Earth Planet. Sci. Lett. 1978, 38, 129-176. [CrossRef]

58. Guo, F.; Li, H.X.; Fan, W.M.; Li, J.Y.; Zhao, L.; Huang, M.W. Variable sediment flux in generation of Permain subduction related mafic intrusions from the Yanbian region, NE China. Lithos 2015, 261, 195-215. [CrossRef]

59. Wilson, M. Igneous Petrogenesis; Unwin Hyman Press: London, UK, 1989; pp. 1-466.

60. Pearce, J.A. Role of the Sub-Continental Lithosphere Inmagma Genesis at Active Continental Margins. In Continental Basalts and Mantle Xenoliths; Hawkesworth, C.J., Norry, M.J., Eds.; Birkhauser: Nantwich, Switzerland, 1983; pp. 230-249.

61. Puchtel, I.S.; Hofmann, A.W.; Mezger, K.; Jochum, K.P.; Shchipansky, A.A.; Samsonov, A.V. Oceanic plateau model for continental crustal growth in the Achaean: A case study from the Kostomuksha greenstone belt, NW Baltic Shield. Earth Planet. Sci. Lett. 1998, 155, 57-74. [CrossRef]

62. Zhao, J.H.; Zhou, M.F. Geochemistry of Neoproterozoic mafic intrusions in the Panzhihua district (Sichuan Province, SW China): Implications for subduction-related metasomatism in the upper mantle. Precambrian Res. 2007, 152, 27-47. [CrossRef]

63. Morrison, G.W. Characteristics and tectonic setting of the shoshonite rock association. Lithos 1980, 13, 97-108. [CrossRef]

64. Bitencourt, M.F.; Nardi, L.V.S. The role of xenoliths and flow segregation in the genesis and evolution of the Paleoproterozoic Itapema Granite, a crustally derived magma of shoshonitic affinity from southern Brazil. Lithos 2004, 73, 1-19. [CrossRef]

65. Zhao, Z.H.; Xiong, X.L.; Wang, Q.; Bai, Z.W.; Qiao, Y.L. Late Paleozoic underplating in North Xinjiang: Evidence from shoshonites and adakites. Gondwana Res. 2009, 16, 216-226. [CrossRef]

66. Yang, J.H.; Sun, J.F.; Zhang, M.; Wu, F.Y.; Wilde, S.A. Petrogenesis of silicasaturated and silica-undersaturated syenites in the northern North China Craton related to post-collisional and intraplate extension. Chem. Geol. 2012, 328, 149-167. [CrossRef] 
67. Deng, J.F.; Feng, Y.F.; Liu, C.; Xiao, Q.H.; Su, S.G.; Zhao, G.C.; Meng, F.; Ma, S.; Yao, T. Magmatic arc and ocean-continent transition: Discussion. Geol. Rev. 2015, 61, 473-484. (In Chinese with English Abstract).

68. Gill, R.C.O.; Aparicio, A.; El Azzouzi, M.; Hernandez, J.; Thirlwall, M.F.; Bourgois, J.; Marriner, G.F. Depleted arc volcanism in the Alboran Sea and shoshonitic volcanism in Morocco: Geochemical and isotopic constraints on Neogene tectonic processes. Lithos 2004, 78, 363-388. [CrossRef]

69. Kuno, H. High-alumina basalt. J. Petrol. 1960, 1, 121-145. [CrossRef]

70. Crawford, A.J.; Falloon, T.J.; Eggins, S. The origin of island arc high alumina basalts. Contrib. Miner. Petrol. 1987, 97, 417-430. [CrossRef]

71. Eason, D.; Sinton, J. Origin of high-Al N-MORB by fractional crystallization in the upper mantle beneath the Galápagos Spreading Center. Earth Planet. Sci. Lett. 2006, 252, 423-436. [CrossRef]

72. Yu, Q.; Ge, W.C.; Yang, H.; Zhao, G.C.; Zhang, Y.L.; Li, S. Petrogenesis of late Paleozoic volcanic rocks from the Daheshen Formation in central Jilin Province, NE China, and its tectonic implications: Constraints from geochronology, geochemistry and Sr-Nd-Hf isotopes. Lithos 2014, 192, 116-131. [CrossRef]

73. Zhang, S.H.; Zhao, Y.; Song, B.; Yang, Y.H. Zircon SHRIMP U-Pb and in-situ Lu-Hf isotope analyses of a tuff from western Beijing: Evidence for missing Late Paleozoic arc volcano eruptions at the northern margin of the North China block. Gondwana Res. 2007, 12, 157-165. [CrossRef]

74. Li, C.D.; Zhang, F.Q.; Miao, L.C.; Xie, H.Q.; Xu, Y.W. Zircon SHRIMP geochronology and geochemistry of Late Permian high-Mg andesites in Seluohe area, Jilin province, China. Acta Petrol. Sin. 2007, 23, 767-776.

75. Liu, S.; Hu, R.Z.; Gao, S.; Feng, C.X.; Feng, G.Y.; Coulson, I.M.; Li, C.; Wang, T.; Qi, Y.Q. Zircon U-Pb age and $\mathrm{Sr}-\mathrm{Nd}-\mathrm{Hf}$ isotope geochemistry of Permian granodiorite and associated gabbro in the Songliao Block, NE China and implications for growth of juvenile crust. Lithos 2010, 114, 423-436. [CrossRef]

76. Wu, F.Y.; Wilde, S.A.; Zhang, G.L.; Sun, D.Y. Geochronology and Petrogenesis of the Post-orogenic Cu-Ni Sulfide-bearing Mafic-ultramafic Complexes in Jilin Province, NE China. J. Asian Earth Sci. 2004, 23, 781-797. [CrossRef]

77. Xu, W.L.; Ji, W.Q.; Pei, F.P.; Meng, E.; Yu, Y.; Yang, D.B.; Zhang, X.Z. Triassic Volcanism in Eastern Heilongjiang and Jilin Provinces, NE China: Chronology, Geochemistry, and Tectonic Implications. J. Asian Earth Sci. 2009, 34, 392-402. [CrossRef]

78. Liu, Z.H.; Wang, C.; Song, J.; Gao, X.; Sun, L.N. ${ }^{40}$ Ar- ${ }^{39}$ Ar dating and its tectonic significance of the Hulan Group at the northern margin of the North China Plate. Acta Petrol. Sin. 2016, 32, 2757-2764.

(C) 2020 by the authors. Licensee MDPI, Basel, Switzerland. This article is an open access article distributed under the terms and conditions of the Creative Commons Attribution (CC BY) license (http://creativecommons.org/licenses/by/4.0/). 